\title{
Glutopik Analizinin Aynı Kategoride Yer Alan Ekmeklik Buğday Çeşitlerinin (Triticum aestivum L.) Sınıflandırma ve Değerlendirmesinde Kullanılabilirliğinin Belirlenmesi
}

\author{
Gökhan Çeliker ${ }^{1}$, Halef Dizlek ${ }^{2 *}$ \\ ${ }^{1}$ Diyarbakır Ticaret Borsası, Diyarbakır, Türkiye (ORCID: 0000-0002-0165-8619), mrgkan@gmail.com \\ 2 Osmaniye Korkut Ata Üniversitesi, Mühendislik Fakültesi, Gıda Mühendisliği Bölümü, Osmaniye, Türkiye (ORCID: 0000-0001-5873-5462), \\ hdizlek@osmaniye.edu.tr
}

(İlk Geliş Tarihi 2 Eylül 2020 ve Kabul Tarihi 25 Ekim 2020)

(DOI: 10.31590/ejosat.796345)

ATIF/REFERENCE: Çeliker, G. \& Dizlek, H. (2020). Glutopik Analizinin Aynı Kategoride Yer Alan Ekmeklik Buğday Çeşitlerinin (Triticum aestivum L.) Sınıflandırma ve Değerlendirmesinde Kullanılabilirliğinin Belirlenmesi. Avrupa Bilim ve Teknoloji Dergisi, (20), 409-424.

$\ddot{O} z$

Çalışmada TS 2974 Buğday standardına göre aynı kategoride yer alan ekmeklik buğday çeşitlerinin (Triticum aestivum L.) Farinograf ve Ekstensograf özelliklerinin belirlenerek TMO hububat alım kriterleriyle uyumluluğunun incelenmesi ve Glutopik analizinin bu sınıflandırma ve değerlendirme çerçevesinde kullanılabilirliğinin belirlenmesi hedeflenmiştir. Sunulan çalışma iki kısımdan oluşmaktadır: Birinci kısımda; temel teknolojik ve reolojik özellikleri saptanan 6 farklı buğday örneğinde tavlı, tavsız ve tam buğday unu şeklinde üç farklı öğütme tekniği uygulanmış olup örneklere glutopik analizi ayrıca uygulanmıştır. İkinci kısımda ise, TS 2974 buğday standardına göre sınıflandırılan 36 farklı buğday çeşidiyle analizler gerçekleştirilmiştir. Glutopik cihazının düşük numune miktarı ihtiyacı, kısa analiz süresi ve gluten yapısı hakkında bilgi vermesi avantajlı yönlerini oluştururken, elde edilen verilerin değişkenliğinin çok olması ve araşıırma devam ederken üretici firmanın cihazla ilgili yazılımı güncellemesi Glutopik üzerinde daha fazla çalışma yapılmasına gereksinim olduğunu göstermiş̧tir. Bununla birlikte maksimum tork değeri yüksek olan buğday unlarının su absorbsiyonlarının yüksek olduğu, $\mathrm{A}(0-5)$ arası alan ve mesafenin büyümesine koşut olarak hamurun direnç ve uzama yeteneğinin arttığı, elastikiyetinin geliştiği belirlenmiştir. Birinci kısımda Glutopik parametreleri ile Ekstensograf uzama kabiliyeti arasında daha fazla ilişki kurulmuşken, ikinci kısımda Glutopik parametreleri ile daha çok Ekstensograf enerji değeri arasında ilişki kurulmuştur. Farinograf su absorbsiyon değeri ile maksimum tork arasında (her iki kısım çalışmada da aynı düzeyde) pozitif yönde ilişki olduğu görülmüştür.

Anahtar Kelimeler: Ekmeklik buğday, TS 2974 Buğday standard1, Tasnif, Glutopik.

\section{Determination of the Usability of Glutopeak Analysis on Classification and Evaluation of Bread Wheat Varieties (Triticum aestivum L.) in the Same Category}

\begin{abstract}
In this study, firstly Farinograph and Extensograph properties of bread wheat varieties (Triticum aestivum L.) in the same category according to the TS 2974 Wheat standard were determined. Then it is aimed to determine the examination of compliance with the Soil Products Office's grain purchase criteria and the availability of Glutopeak analysis within the frame of classification and evaluation. The presented study consists of two parts: In the first part; three different grinding techniques in the form of tempered, no tempered and whole wheat flour were applied to 6 different wheat samples whose basic technological and rheological properties were determined, and glutopeak analysis was also applied to the samples. In the second part, 36 different wheat varieties classified according to the TS 2974 wheat standard were analyzed. While the requirement of low amount of sample, short analysis time and giving information about gluten structure are creating the advantageous aspects of Glutopeak device; the large variability of obtained data and when the research continues producing company's updating the software about device have suggested the necessity for further work needed to be done with the Glutopeak device. In addition to this, it is determined that the water absorption of wheat flour
\end{abstract}

* Sorumlu Yazar: hdizlek@osmaniye.edu.tr 
is high whose maximum torque value is high, the dough's resistance and extensibility increased and elasticity improved in parallel with $\mathrm{A}(0-5)$ area and distance's increasing. In the first part, a more correlation was established between Glutopeak parameters and Extensograph extensibility, while in the second part, a correlation was established between Glutopeak parameters and Extensograph energy value. It has been observed that there is a positive correlation between the Farinograph water absorption value and the maximum torque (at the same level in both parts study).

Keywords: Bread wheat, TS 2974 Wheat standard, Classification, Glutopeak.

\section{Giriş}

Buğdaylar, Türkiye'de TS 2974 (TSE, 2018) Buğday standardı çerçevesinde hazırlanan TMO Alım bareminde belirlenen kriterler doğrultusunda, yetkili sınıflandırıcı laboratuvarlar tarafindan siniflandirılmaktadır. Ancak aynı grup ve sınıfta yer alması nedeniyle aynı depoda sınıflandırılan bazı ekmeklik buğday çeşitlerinin piyasada farklı fiyatlar üzerinden alınıp-satıldığı görülmektedir. Piyasada farklı fiyatlardan alınıp satılan ekmeklik buğday çeşitlerinin lisanslı depolarda aynı sınıfta depolanması ve depolanan ürünün piyasa fiyatının daha düşük gerçekleşmesi, ürünlerin lisanslı depoya götürülmeme riskini doğurmaktadır. Bu durum; depolamada reolojik değerler açısından yüksek kaliteli buğday çeşitlerinin diğer kalite bandındaki çeşitler ile karışmasına ve orta seviyede bir kalite sınıfının ortaya çıkmasına, ekmeklik buğday piyasasında yüksek kalitedeki buğday arzının düşmesine, bu nedenle iç piyasada kaliteli buğday piyasa fiyatlarının yükselmesine ve buğday ithalatının artmasına sebep olmaktadır (Dizlek ve Çeliker, 2017; Çeliker ve Dizlek, 2020).

Türkiye, özelde durum buğdayı ( $T r$. durum) genelde ise buğday üretiminde bölgesel olarak önemli bir aktördür. Ekmeklik buğdayda kalite kriterlerinin genel itibari ile \%10-14 nem miktarına sahip, yabancı madde içeriği az, hektolitre ağırlığı yüksek, homojen (irilik bakimindan yeknesak) yapıda, ait olduğu tür ve çeşidin karakteristik özelliklerini taşıyan, yüksek un verimine sahip, protein ve gluten miktarı ile gluten kalitesi yüksek ve yeterli enzim etkinlik düzeyine sahip olması istenir (Posner ve Hibbs, 1997; Dizlek ve Özer, 2016).

Protein ve gluten miktarı, gluten indeks, sedimantasyon değerleri, düşme sayısı ve fiziksel analizler buğday kalite değerlendirilmesinde yaygın olarak kullanılmakla birlikte, kalite hakkında sınırlı bilgilere ulaşılmakta ve bazı analizlerin tekrarlanabilirliği düşük ölçekte gerçekleşmektedir (Chandi ve Seetharaman, 2012). Hamurun reolojik özelliklerini belirleyen analizler (Farinograf, Ekstensograf, Alveograf, Miksograf vb.) daha kapsamlı bilgiler sağlayan, tekrarlanabilirliği yüksek testlerdir (Lukow ve ark., 1989). Ancak analiz sürelerinin uzun olması ve fazla miktarda numuneye ihtiyaç duyulması, bu reolojik analizlerin kullanılmasını kısıtlamaktadır (Chandi ve Seetharaman, 2012; Karaduman ve ark., 2015). Bu nedenle gluten kalitesinin tahmin edilebilmesi için, kısa süreli ve az numune ile çalışma yapılabilen yeni tekniklere ihtiyaç duyulmaktadır. Buna yönelik yapılan araştırmalar sonucunda, Glutopik cihazı ile hızlı bir şekilde buğday kalitesi hakkında bilgi edinildiği ifade edilmiştir (Anonymus, 2018; Karaduman ve ark., 2019; Zawieja ve ark., 2020). Bu cihazın temel prensibi; belirli oranlardaki un-su karışımına uygulanan farklı yoğurma kuvveti (0-3000 d d $\mathrm{d}^{-1}$ arası) ve bu kuvvete karşı oluşan tepkinin ve sürenin ölçülmesi, yani ilkin gluten ve gluten ağı oluşumu ve devam eden hızlı yoğurma ile oluşan ağın parçalanması ilkesine dayanmaktadır. Bu analizin temel çıktıları; maksimum noktaya ulaşmak için geçen süre, pik yüksekliği ve takip eden pikteki azalışın ölçülmesi olup, oldukça kısa süre içerisinde (buğday çeşidine göre değişmekle birlikte genel itibari ile 1-4 d arasında) ölçüm yapılabilmektedir (Karaduman ve ark., 2015).

Buğday unu sektöründe nispeten yeni bir ekipman olan Glutopik cihazı ile son yıllarda bazı çalışmalar yapılmıştır (Melnyk, 2011; Chandi ve Seetharaman, 2012; Brunnbauer ve ark., 2012; Marti ve ark., 2014 ve 2015; Karaduman ve ark., 2015 ve 2019; Sissons, 2016; Wang ve ark., 2017 ve 2018; Şanal ve ark., 2018; Malegori ve ark., 2018; Zawieja ve ark., 2020; Şahin ve ark., 2020). Genel olarak söz konusu araştırmalarda, buğday kalitesinin değerlendirilmesinde Glutopik parametrelerinin kullanılabilirliği araştırılmıştır. Daha önce bir örneğine rastlamadığımız bu çalışmada, diğer vasıfları aynı hale getirilerek sadece protein miktarına göre sınıflandırılan ve temel reolojik özellikleri ortaya konulan muhtelif ekmeklik buğday çeşitlerinin (Triticum aestivum L.), Glutopik analizleri yapılarak buğday sınıflandırmasında Glutopik cihazının kullanılabilirliği değerlendirilmiştir.

\section{Materyal ve Metot}

\subsection{Materyal}

Protein miktarının sınıflandırmadaki etkisini belirleyerek ortaya koymak amacıyla araştırmada kullanılan buğday örnekleri, öncelikle TS 2974 (TSE, 2018) doğrultusunda hazırlanan 2017-2018 Dönemi Hububat Alım Baremine göre, protein dışındaki diğer parametreleri müsavi (birbirine denk) hale getirmek için safiyet analizleri yapılmış (analiz yapılan numune içerisinde bulunan saf tohum ve numune ile istenmeyen diğer komponentlerin [diğer mahsül, ot tohumları, zararlı ot tohumları ve cansız yabancı madde vb.] ağırlıkça yüzde oranları tespit edilmiş), tüm numuneler TS 2974 standardı doğrultusunda aynı sınıfta olacak şekilde saf tohum dişında kalan komponentleri ayıklanmış ve temizlenmiştir. Böylelikle buğday numuneleri sadece protein miktarına göre sinıflandırılabilecek duruma getirilmiştir. Müsavi hale getirilen numunelerin TS 2974 (TSE, 2018) ve TMO Alım Bareminde (TMO, 2018) belirtilen metotlar doğrultusunda analizleri yapılmış ve bu kriterlere göre buğday grupları ile sınıfları tespit edilmiştir. Araştırmada kullanılan materyal ve bu materyalin temel özellikleri Çeliker ve Dizlek (2020)'de detaylı olarak belirtilmiştir. Yine "Buğday Grupları ve Sınıflarının Oluşturulması" ile "Buğday Gruplarının Sınıflandırılması ve Numuneleri Kırma İşlemleri” ayrı alt başlıklar halinde söz konusu makalede verilmiş, bu nedenle burada verilmemiştir.

\subsection{Buğday Kalite Analizleri}

Hazırlanan numunelerin rutubet ve protein miktarı tayinleri TS EN 15948 (TSE, 2015a), yaş gluten miktarı ve gluten indeks değeri TS EN ISO 21415-2 (TSE, 2016), sedimantasyon endeksi TS EN ISO 5529 (TSE, 2013a), gecikmeli sedimantasyon testi Greenaway ve ark. (1965), düşme sayısı TS EN ISO 3093 (TSE, 2013b), Farinograf ve Ekstensograf analizleri ise sirasiyla TS EN ISO 5530-1 (TSE, 2015b) ve TS EN ISO 5530-2 (TSE, 2015c) metotlarına göre yapılmıştır. 


\subsection{Glutopik Analizi}

Protein, Farinograf ve Ekstensograf değerleri belirlenen buğday numuneleri, aralarındaki olası farkı ortaya koymak açısından üç farklı buğday kırma metodu ile öğütülmüş (tavlı, tavsız ve tam buğday unu olarak [tavlı öğ̈̈tülen buğdayların un randımanı \%60-65, tavsız öğütülen buğdayların un randımanı ise \%40-45 aralığında belirlenmiştir]) ve Glutopik cihazında analizleri yapılmıştır. Çalışmada Glutopik ölçümlerinde Melnyk (2011) tarafından kullanılan yöntem esas alınmıştır. Buna göre, bir numune kabına toplamda $18 \mathrm{~g}$ olacak şekilde (\%14 rutubete göre 8.5 g numune ve 9.5 g $0.5 \mathrm{M} \mathrm{CaCl}_{2}$ çözeltisi) eklenmiş, sabit $1900 \mathrm{~d} \mathrm{~d}^{-1}$ 'da dönen bıçağın uyguladığı torka karşı oluşan direnç ölçülmüştür.

Glutopik cihazından elde edilen grafikten Maksimum tork (BEM), Maksimum pik süresi (PMT), Maksimum torktan $15 \mathrm{~s}$ önceki tork değeri (AM), Maksimum torktan $15 \mathrm{~s}$ sonraki tork değeri (PM), A0 ile A1 arası alan $(\mathrm{A}(0-1))$, A1 ile $\mathrm{A} 2$ arasi alan $(\mathrm{A}(1-2)), \mathrm{A} 2$ ile $\mathrm{A} 3$ aras1 alan $(\mathrm{A}(2-3)), \mathrm{A} 3$ ile $\mathrm{A} 4$ aras1 alan (A(3-4)) ve A4 ile A5 arası alan (A(4-5)) belirlenmiştir (Şekil 1).

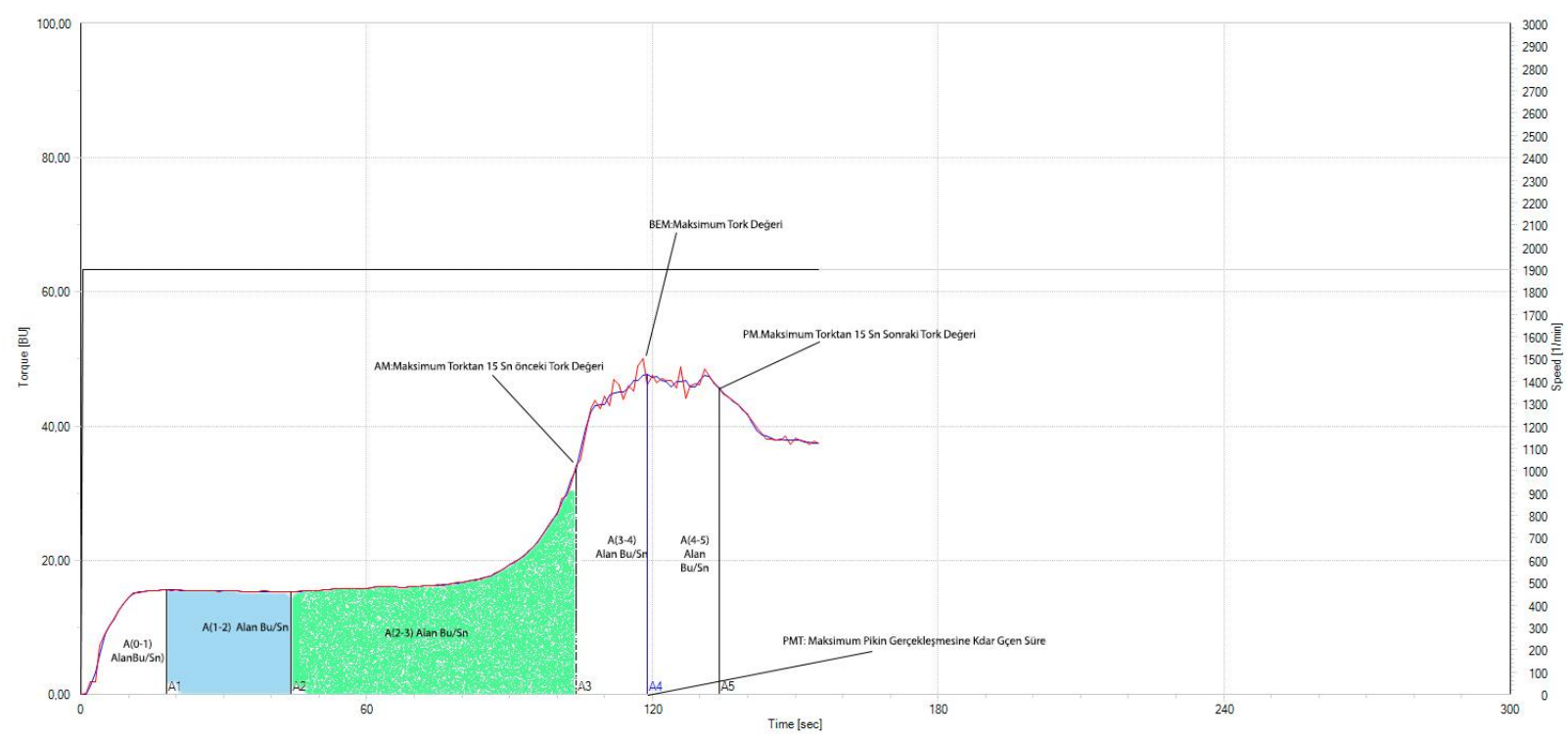

Şekil 1. Örnek bir Glutopik Grafiği

Glutopik cihazının yazılım güncelleme çalışmalarının devam ediyor olması ve parametreleri ile ilgili net bir bilginin tarafımıza sunulamamış olması, ayrıca yapılan çalışmalarda birbirinden oldukça farklı metotların kullanılmış olması ve literatürde birbirleriyle çelişen bulguların varlığı nedeniyle çalışma iki kısımdan oluşturulmuştur:

Birinci kısımda; protein, Farinograf ve Ekstensograf değerleri bilinen numuneler ile Glutopik analizleri yaparak cihazın parametreleri (BEM, PMT, AM, PM, A(0-1), A(1-2), $\mathrm{A}(2-3), \mathrm{A}(3-4)$ ve $\mathrm{A}(4-5))$ hakkında daha net bilgi edinilmeye çalışılmıştır.

Ikkinci kısımda; TS 2974 (TSE, 2018) buğday standardına göre sınıflandırılan 36 çeşit numune ile analizler yapılmıştır. Cihazın yeni yazılımında; $\mathrm{A}(0-1)$ alan adı "Start-up energy (Başlangıç enerjisi)", A(1-2) alan adı "Plateau energy (Plato enerjisi)" olarak adlandırılmış olup, A(2-3) parametresi yeni parametreler arasından çıkarılmış ve A(3-4) ile A(4-5) alan değerleri birleştirilerek A(3-5) "Aggregation energy (Toplanma enerjisi)" olarak tanımlanmıştır. $\mathrm{Bu}$ nedenle "Araştırma Sonuçları ve Tartışma" kısmında Glutopik cihazı ile gerçekleştirilen ikinci kısım çalışmalarda cihazın yeni parametrelerine yer verilmiştir.

\section{4. İstatistiksel Analizler}

Denemelerde değişkenler arasındaki ilişkinin düzeyi ölçülmeye çalışılmış ve analizleri yapılan buğday-un örneklerine ait değerler arasındaki korelasyon ilişkisi JMP Release 5.0, Windows NT 6.1, SAS Institute 1989-2002 programı ile belirlenmiştir.

\section{Araştırma Sonuçları ve Tartışma}

\subsection{Birinci Kısım Analizler}

\subsubsection{Glutopik Cihazı Parametrelerinin Protein Miktart ile Karşılaştırılması}

Protein ve gluten miktarı farklı olduğu bilinen altı çeşit buğday, Glutopik analizleri için öğütme metodundan kaynaklanacak tesirin de görülebilmesi amacıyla iki farklı şekilde öğütülmüştür: tam buğday unu ve tavlı öğütülmüş buğday unu. Glutopik cihazında yapılan analizlere ait bulgular Çizelge 1 ve 3 'de, bu bulguların protein-gluten miktarları ile korelasyon ilişkisi ise Çizelge 2 ve 4'de verilmiştir. Çizelge 2'de sunulan analiz bulgularına göre, Glutopik cihazı parametrelerinden maksimum pik süresi ile gluten miktarı arasında negatif yönde $0.88(\mathrm{P}<0.01)$ düzeyinde önemli bir ilişkinin olduğu görülmüştür. 
Çizelge 1. Farklı Buğday Çeşitlerinin Tam Buğday Unu Numunelerine Ait Protein-Gluten Miktarları İle Bu Buğdayların Glutopik Analiz Sonuçlarının Karşılaştııılması

\begin{tabular}{|c|c|c|c|c|c|c|c|c|c|c|c|c|}
\hline $\begin{array}{l}\text { Tam } \\
\text { Buğday } \\
\text { Unu }\end{array}$ & $\begin{array}{c}\text { Protein } \\
\text { Miktarı } \\
(\%)\end{array}$ & $\begin{array}{l}\text { Gluten } \\
\text { Miktarı } \\
(\%)\end{array}$ & $\begin{array}{c}\text { Gluten } \\
\text { İndeks } \\
(\%)\end{array}$ & PMT & BEM & (BU) & (BU) & $\begin{array}{l}\text { A(0-1) } \\
\text { (GPI, } \\
\text { Alan) }\end{array}$ & $\begin{array}{l}\text { A(1-2) } \\
\text { (GPI, } \\
\text { Alan) }\end{array}$ & $\begin{array}{l}\mathrm{A}(2-3) \\
\text { (GPI, } \\
\text { Alan) }\end{array}$ & $\begin{array}{l}\text { A(3-4) } \\
\text { (GPI, } \\
\text { Alan) }\end{array}$ & $\begin{array}{c}\mathrm{A}(4-5) \\
\text { (GPI, } \\
\text { Alan) }\end{array}$ \\
\hline Adana-99 & 12.4 & 24.5 & 95 & 82 & 45 & 22 & 34 & 1451 & 1451 & 914 & 537 & 572 \\
\hline Abuşbey & 12.9 & 38.8 & 57 & 59 & 53 & 48 & 44 & 1353 & 155 & 512 & 769 & 703 \\
\hline Bahaki & 13.6 & 37.8 & 44 & 63 & 54 & 25 & 46 & 119 & 64 & 593 & 673 & 746 \\
\hline Sibirya & 14.3 & 33.9 & 81 & 80 & 54 & 51 & 41 & 1890 & 322 & 643 & 804 & 675 \\
\hline Wafia & 15.9 & 41.9 & 45 & 54 & 50 & 25 & 40 & 1243 & 1243 & 637 & 606 & 670 \\
\hline GWB-47 & 16.7 & 42.4 & 60 & 42 & 81 & 66 & 64 & 2144 & 2144 & 1049 & 1095 & 1072 \\
\hline
\end{tabular}

PMT: Maksimum pik süresi, BEM: Maksimum tork, AM: Maksimum torktan $15 \mathrm{~s}$ önceki tork değeri, PM: Maksimum torktan $15 \mathrm{~s}$ sonraki tork değeri, A(0-1): A0 ile $\mathrm{A} 1$ arası alan, $\mathrm{A}(1-2)$ : $\mathrm{A} 1$ ile $\mathrm{A} 2$ arası alan, $\mathrm{A}(2-3)$ : $\mathrm{A} 2$ ile $\mathrm{A} 3$ arası alan, $\mathrm{A}(3-4)$ : $\mathrm{A} 3$ ile $\mathrm{A} 4$ arası alan, $\mathrm{A}(4-5)$ : $\mathrm{A} 4$ ile $\mathrm{A} 5$ arası alan.

Çizelge 2. Çizelge 1'de Verilen Buğday Çeşitlerinin Tam Buğday Unu Numunelerine Ait Protein-Gluten Miktarları İle Bu Buğdayların Glutopik Analiz Sonuçlarının Korelasyon İlişkisi

\begin{tabular}{lccccccccc}
\hline $\begin{array}{l}\text { Tam Buğday } \\
\text { Unu }\end{array}$ & $\begin{array}{c}\text { PMT } \\
(\mathrm{s})\end{array}$ & $\begin{array}{c}\text { BEM } \\
\text { (BU) }\end{array}$ & $\begin{array}{c}\text { AM } \\
\text { (BU) }\end{array}$ & $\begin{array}{c}\text { PM } \\
\text { (BU) }\end{array}$ & $\begin{array}{c}\text { A(0-1) } \\
\text { (GPI, Alan) }\end{array}$ & $\begin{array}{c}\text { A(1-2) } \\
\text { (GPI, Alan) }\end{array}$ & $\begin{array}{c}\text { A(2-3) } \\
\text { (GPI, Alan) }\end{array}$ & $\begin{array}{c}\text { A(3-4) } \\
\text { (GPI, Alan) }\end{array}$ & $\begin{array}{c}\text { A(4-5) } \\
\text { (GPI, Alan) }\end{array}$ \\
\hline Protein & -0.73 & 0.72 & 0.47 & 0.68 & 0.4 & 0.58 & 0.38 & 0.62 & 0.72 \\
Gluten & $-0.88^{* *}$ & 0.58 & 0.43 & 0.66 & 0 & 0.05 & -0.18 & 0.55 & 0.64 \\
Gluten indeks & 0.74 & -0.23 & 0.03 & -0.39 & 0.5 & 0.21 & 0.42 & -0.15 & -0.35
\end{tabular}

PMT: Maksimum pik süresi, BEM: Maksimum tork, AM: Maksimum torktan $15 \mathrm{~s}$ önceki tork değeri, PM: Maksimum torktan $15 \mathrm{~s}$ sonraki tork değeri, A(0-1): A0 ile

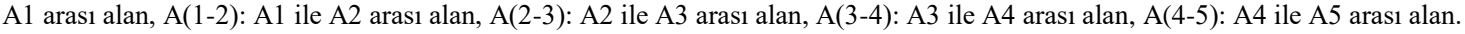

$* \mathrm{P}<0.05$ seviyesinde önemli, $* * \mathrm{P}<0.01$ seviyesinde önemli.

Çizelge 3. Farklı Buğday Çeşitlerinin Tavlı Öğ̈̈̈tülmüş Buğday Unu Numunelerine Ait Protein-Gluten Miktarları İle Bu Buğdayların Glutopik Analiz Sonuçlarının Karşılaştırılması

\begin{tabular}{|c|c|c|c|c|c|c|c|c|c|c|c|c|}
\hline $\begin{array}{l}\text { Tavlı } \\
\text { Öğütülmüş } \\
\text { Un }\end{array}$ & $\begin{array}{c}\text { Protein } \\
\text { Miktarı } \\
(\%)\end{array}$ & $\begin{array}{c}\text { Gluten } \\
\text { Miktarı } \\
(\%)\end{array}$ & $\begin{array}{c}\text { Gluten } \\
\text { İndeks } \\
(\%)\end{array}$ & PMT & BEM & (BU) & (BU) & $\begin{array}{l}\text { A(0-1) } \\
\text { (GPI, } \\
\text { Alan) }\end{array}$ & $\begin{array}{l}\text { A(1-2) } \\
\text { (GPI, } \\
\text { Alan) }\end{array}$ & $\begin{array}{l}\mathrm{A}(2-3) \\
\text { (GPI, } \\
\text { Alan) }\end{array}$ & $\begin{array}{l}\text { A(3-4) } \\
\text { (GPI, } \\
\text { Alan) }\end{array}$ & $\begin{array}{l}\mathrm{A}(4-5) \\
\text { (GPI, } \\
\text { Alan) }\end{array}$ \\
\hline Adana-99 & 12.4 & 24.5 & 95 & 135 & 46 & 37 & 40 & 258 & 437 & 1176 & 666 & 662 \\
\hline Abuşbey & 12.9 & 38.8 & 57 & 56 & 52 & 29 & 45 & 1410 & 1410 & 730 & 680 & 740 \\
\hline Babahaki & 13.6 & 37.8 & 44 & 67 & 51 & 24 & 44 & 123 & 161 & 556 & 635 & 739 \\
\hline Sibirya & 14.3 & 33.9 & 81 & 114 & 54 & 52 & 47 & 149 & 101 & 2573 & 767 & 736 \\
\hline Wafia & 15.9 & 41.9 & 45 & 48 & 49 & 25 & 41 & 1106 & 1106 & 544 & 562 & 694 \\
\hline GWB-47 & 16.7 & 42.4 & 60 & 62 & 59 & 52 & 50 & 1485 & 336 & 557 & 844 & 818 \\
\hline
\end{tabular}

PMT: Maksimum pik süresi, BEM: Maksimum tork, AM: Maksimum torktan $15 \mathrm{~s}$ önceki tork değeri, PM: Maksimum torktan $15 \mathrm{~s}$ sonraki tork değeri, A(0-1): A0 ile A1 aras1 alan, A(1-2): A1 ile A2 arasi alan, A(2-3): A2 ile A3 aras1 alan, A(3-4): A3 ile A4 aras1 alan, A(4-5): A4 ile A5 aras1 alan.

Çizelge 4. Çizelge 3'de Verilen Buğday Çeşitlerinin Tavlı Öğ̈̈̈ülmüş Buğday Unu Numunelerine Ait Protein-Gluten Miktarları İle Bu Buğdayların Glutopik Analiz Sonuçlarının Korelasyon İlişkisi

\begin{tabular}{|c|c|c|c|c|c|c|c|c|c|}
\hline $\begin{array}{l}\text { Tavlı } \\
\text { Öğütülmüş } \\
\text { Un }\end{array}$ & $\begin{array}{l}\text { PMT } \\
\text { (s) }\end{array}$ & $\begin{array}{l}\text { BEM } \\
(\mathrm{BU}) \\
\end{array}$ & $\begin{array}{l}\mathrm{AM} \\
(\mathrm{BU})\end{array}$ & $\begin{array}{c}\mathrm{PM} \\
(\mathrm{BU})\end{array}$ & $\begin{array}{c}\mathrm{A}(0-1) \\
\text { (GPI, Alan) }\end{array}$ & $\begin{array}{c}\mathrm{A}(1-2) \\
\text { (GPI, Alan) }\end{array}$ & $\begin{array}{c}\mathrm{A}(2-3) \\
\text { (GPI, Alan) }\end{array}$ & $\begin{array}{c}\mathrm{A}(3-4) \\
\text { (GPI, Alan) }\end{array}$ & $\begin{array}{c}\mathrm{A}(4-5) \\
\text { (GPI, Alan) }\end{array}$ \\
\hline Protein & -0.52 & 0.64 & 0.34 & 0.5 & 0.51 & -0.07 & -0.21 & 0.31 & 0.59 \\
\hline Gluten & $-0.93 * *$ & 0.61 & -0.12 & 0.49 & 0.67 & 0.32 & -0.47 & 0.06 & 0.66 \\
\hline $\begin{array}{l}\text { Gluten } \\
\text { İndeks }\end{array}$ & $0.94 * *$ & -0.23 & 0.56 & -0.12 & -0.41 & -0.35 & 0.66 & 0.35 & -0.36 \\
\hline
\end{tabular}

PMT: Maksimum pik süresi, BEM: Maksimum tork, AM: Maksimum torktan $15 \mathrm{~s}$ önceki tork değeri, PM: Maksimum torktan 15 s sonraki tork değeri, A(0-1): A0 ile A1 aras1 alan, A(1-2): A1 ile A2 aras1 alan, A(2-3): A2 ile A3 aras1 alan, A(3-4): A3 ile A4 aras1 alan, A(4-5): A4 ile A5 aras1 alan.

$* \mathrm{P}<0.05$ seviyesinde önemli, $* * \mathrm{P}<0.01$ seviyesinde önemli.

Çizelge 4'de tavlı ögütülmüş un numunelerinde yapılan Glutopik analizi neticesinde, gluten miktarı ile maksimum pik süresi arasında $\mathrm{r}=-0.93(\mathrm{P}<0.01)$ düzeyinde negatif yönde korelasyon olduğu, gluten indeks değeri ile $\mathrm{r}=0.94(\mathrm{P}<0.01)$ düzeyinde pozitif yönde bir korelasyon ilişkisi saptanmıştır. Sonuç olarak, maksimum pik süresi ile gluten miktarı arasında negatif, gluten indeks değeri arasında ise pozitif yönde korelasyon olduğu görülmüştür. Elgün ve Ertugay (1997), unun gluten miktarındaki artışın gelişme süresini arttırdığını bildirmişlerdir. Buna göre gluten miktarı ile maksimum pik süresi arasında pozitif yönde bir ilişki olması beklenir. $\mathrm{Bu}$ çalışmada gluten miktarı artışının unun su absorbe etme hızını arttırdığ 


\subsubsection{Glutopik Cihazı Parametrelerinin Ekstensograf Değerleri ile Karşılaştırılması}

Araştırmanın bu bölümünde altı farklı buğday çeşidi ile çalışılmıştır. Bunlar yerli buğday çeşitleri olan Pandas, Bezostaja, Adana-99 ile ithal buğday çeşitleri Litvanya, Sibirya ve Rus buğdaylarıdır (Çizelge 5). Ekstensograf analizleri (Çizelge 6) yapılan bu çeşitlerin uzaya bilirlik değerleri ile tavlı, tavs1z ve tam buğday unu olarak öğütülmüş numunelerin Glutopik analiz sonuçları Çizelge 7'de verilmiştir.

Çizelge 5. Üç Farklı Metotla Kırılmış Altı Çeşit Buğday Numunesinin (Pandas, Bezostaja, Adana-99, Litvanya, Sibirya, Rus) Ekstensograf 135. d Uzama Yeteneği Değerleri İle Yüksek Korelasyon İlişkisi Gösteren Glutopik Parametreleri

\begin{tabular}{lcccc}
\hline Un Örneği & BEM & AM & A(2-3) & A(3-4) \\
\hline Tavlı & $0.80^{*}$ & $0.88^{*}$ & $0.96^{* *}$ & $0.90^{*}$ \\
Tavsız & 0.62 & 0.65 & 0.71 & 0.71 \\
Tam Buğday & $0.85^{*}$ & $0.89^{*}$ & 0.22 & $0.95^{* *}$ \\
\hline
\end{tabular}

BEM: Maksimum tork, AM: Maksimum torktan 15 s önceki tork değeri, A(2-3): A2 ile A3 aras1 alan, A(3-4): A3 ile A4 aras1 alan. $* \mathrm{P}<0.05$ seviyesinde önemli, $* * \mathrm{P}<0.01$ seviyesinde önemli.

Çizelge 5'de görüleceği üzere, Ekstensograf analizinin 135. dakikasındaki ölçüme ilişkin uzama kabiliyeti ile Glutopik maksimum tork, maksimum tork sonrası tork, $\mathrm{A}(2-3)$ ve $\mathrm{A}(3-4)$ alan değerleri arasında çok yüksek düzeyde pozitif bir korelasyon olduğu görülmüştür. 135. dakikadaki uzama kabiliyetinin maksimum tork değeri ile tavlı kırılmış numune üzerinde yapılan analizinde, $\mathrm{r}=0.80(\mathrm{P}<0.05)$ oranında bir ilişki gözlenmişken, çekiçli değirmende öğütülmüş numunede ise ilişkinin $\mathrm{r}=0.85(\mathrm{P}<0.05)$ düzeyinde gerçekleştiği görülmüştür. 135. dakikadaki uzama kabiliyetinin maksimum tork 15 s sonrası tork değeri ile ilişkisine bakıldığında, tavlı kırılmış numunede $0.88(\mathrm{P}<0.05)$ ve çekiçli değirmende kırılmış tam buğday unu numunesinde ise $0.89 \quad(\mathrm{P}<0.05)$ düzeyinde ilişki olduğu görülmüştür. 135. dakikadaki hamur uzama yeteneğinin tavlı kırılmış numunenin Glutopik analiz parametresi olan $\mathrm{A}(2-3)$ değeri ile $r=0.96(\mathrm{P}<0.01)$ düzeyinde oldukça yüksek olan ilişkisinin tavsız ve tam buğday unu numunelerinde çok düşük olduğu görülmüştür. 135. dakikadaki uzama kabiliyetinin tavlı un numunesinin $\mathrm{A}(3-4)$ değeri ile $0.90(\mathrm{P}<0.05)$ düzeyinde olan ilişkisi, tam buğday ununda $0.95 \quad(\mathrm{P}<0.01)$ düzeyinde gerçekleşmiştir. Sonuçların incelenmesiyle; ortamda bulunan suyun absorbe edilmeye başlandığı $\mathrm{A}(2-3)$ alan ile suyun maksimum absorbe edildiği an olduğunu değerlendirdiğimiz maksimum torka kadar geçen kısım olan A(3-4) alanlarının büyüklüğü, çeşidin uzama kabiliyeti ile pozitif yönde bir ilişki göstermiştir.

Çalışmada kullanılan numunelerin Glutopik sonuçları ile Ekstensograf maksimum direnç değerleri Çizelge 6'da, Ekstensograf 135. d maksimum direnç değerleri ile maksimum pik süresi arasındaki korelasyon ilişkisi ise Çizelge 8'de sunulmuştur. Çizelge 8 'de verilen korelasyon düzeyleri karşılaştırmasında, tavlı un numunesinde maksimum pik süresi ile Ekstensograf 135. d maksimum direnç değeri arasında $\mathrm{r}=$ 0.74 düzeyinde ilişki görülmüştür. 
Avrupa Bilim ve Teknoloji Dergisi

Çizelge 6. Glutopik Analizleri Yapılan Altı Farklı Buğday Çeşidinin Bazı Ekstensograf Ve Su Absorbsiyon İle Düşme Sayısı Değerleri

\begin{tabular}{|c|c|c|c|c|c|c|c|c|c|c|c|}
\hline \multirow[b]{2}{*}{ Örnek Adı } & \multicolumn{3}{|c|}{ 45. $d$} & \multicolumn{3}{|c|}{ 90. d } & \multicolumn{3}{|c|}{ 135. d } & \multirow[b]{2}{*}{$\begin{array}{c}\mathrm{Su} \\
\text { Absorbsiyonu } \\
\text { (500 FU) [\%] }\end{array}$} & \multirow[b]{2}{*}{$\begin{array}{l}\text { Düşme } \\
\text { Sayıs1 } \\
\text { (s) }\end{array}$} \\
\hline & $\begin{array}{l}\text { Enerji } \\
\left(\mathrm{cm}^{2}\right)\end{array}$ & $\begin{array}{l}\text { Uzama } \\
\text { Kabiliyeti } \\
(\mathrm{mm})\end{array}$ & $\begin{array}{l}\text { Maksimum } \\
\text { Direnç } \\
\text { (BU) }\end{array}$ & $\begin{array}{c}\text { Enerji } \\
\left(\mathrm{cm}^{2}\right)\end{array}$ & $\begin{array}{l}\text { Uzama } \\
\text { Kabiliyeti } \\
(\mathrm{mm})\end{array}$ & $\begin{array}{l}\text { Maksimum } \\
\text { Direnç } \\
\text { (BU) }\end{array}$ & $\begin{array}{c}\text { Enerji } \\
\left(\mathrm{cm}^{2}\right)\end{array}$ & $\begin{array}{l}\text { Uzama } \\
\text { Kabiliyeti } \\
(\mathrm{mm})\end{array}$ & $\begin{array}{l}\text { Maksimum } \\
\text { Direnç } \\
\text { (BU) }\end{array}$ & & \\
\hline Pandas & 106 & 166.1 & 480 & 95.7 & 162.9 & 441.3 & 106 & 166.1 & 480.1 & 62 & 473 \\
\hline Rus (İthal) & 115.9 & 171.1 & 519.6 & 141.1 & 171.3 & 643.6 & 148.7 & 171.4 & 666.5 & 59 & 395 \\
\hline Bezostaja & 71.6 & 136 & 384.7 & 71.7 & 130.9 & 419.5 & 67.2 & 122.7 & 418.4 & 60 & 415 \\
\hline Litvanya (İthal) & 87.3 & 167.9 & 382.5 & 102.9 & 170 & 453.9 & 88.8 & 156.9 & 424.4 & 61 & 324 \\
\hline Adana-99 & 103.6 & 170.4 & 464.1 & 122.2 & 156.5 & 611.7 & 133.7 & 156.9 & 682.9 & 59 & 400 \\
\hline Sibirya (İthal) & 108 & 205.2 & 385.2 & 117.4 & 213.4 & 410.8 & 120.9 & 215.2 & 419.7 & 63 & 358 \\
\hline
\end{tabular}


European Journal of Science and Technology

Çizelge 7. Ü̧̧ Farklı Şekilde Öğ̈̈tülmüş̧ Altı Farklı Buğday Çeşidinin Glutopik Testi Sonuçları

\begin{tabular}{|c|c|c|c|c|c|c|c|c|c|}
\hline Örnek Adları & $\begin{array}{l}\text { PMT } \\
\text { (s) }\end{array}$ & $\begin{array}{l}\text { BEM } \\
\text { (BU) }\end{array}$ & $\begin{array}{l}\mathrm{AM} \\
(\mathrm{BU})\end{array}$ & $\begin{array}{l}\text { PM } \\
(\mathrm{BU})\end{array}$ & $\begin{array}{c}\mathrm{A}(0-1) \\
\text { (GPI, Alan) }\end{array}$ & $\begin{array}{c}\mathrm{A}(1-2) \\
\text { (GPI, Alan) }\end{array}$ & $\begin{array}{c}\mathrm{A}(2-3) \\
\text { (GPI, Alan) }\end{array}$ & $\begin{array}{c}\mathrm{A}(3-4) \\
\text { (GPI, Alan) }\end{array}$ & $\begin{array}{c}\mathrm{A}(4-5) \\
\text { (GPI, Alan) }\end{array}$ \\
\hline \multicolumn{10}{|c|}{ Tavsız Öğütülmüş Buğday Unu (un randımanı \%40-45) } \\
\hline Pandas & 56 & 63 & 57 & 51 & 1540 & 290 & 522 & 881 & 836 \\
\hline Rus (İthal) & 93 & 53 & 51 & 46 & 1459 & 243 & 554 & 780 & 720 \\
\hline Bezostaja & 58 & 54 & 41 & 43 & 1685 & 1685 & 910 & 775 & 709 \\
\hline Litvanya (İthal) & 64 & 57 & 56 & 50 & 1122 & 106 & 379 & 843 & 794 \\
\hline Adana-99 & 69 & 53 & 35 & 42 & 1845 & 1845 & 1099 & 746 & 703 \\
\hline Sibirya (İthal) & 95 & 63 & 60 & 56 & 322 & 78 & 2820 & 924 & 851 \\
\hline \multicolumn{10}{|c|}{ Tavlı Öğütülmüş Buğday Unu (un randımanı \%60-65) } \\
\hline Pandas & 69 & 50 & 45 & 45 & 1829 & 1829 & 1101 & 718 & 731 \\
\hline Rus (İthal) & 126 & 47 & 44 & 38 & 115 & 247 & 1836 & 685 & 642 \\
\hline Bezostaja & 72 & 47 & 25 & 41 & 362 & 81 & 462 & 603 & 691 \\
\hline Litvanya (İthal) & 91 & 48 & 46 & 42 & 117 & 82 & 1459 & 716 & 654 \\
\hline Adana-99 & 135 & 46 & 37 & 40 & 258 & 437 & 1176 & 666 & 662 \\
\hline Sibirya (İthal) & 114 & 54 & 52 & 47 & 149 & 101 & 2573 & 767 & 736 \\
\hline \multicolumn{10}{|c|}{ Tam Buğday Unu } \\
\hline Pandas & 53 & 51 & 27 & 38 & 1198 & 1198 & 1268 & & \\
\hline Rus (İthal) & 64 & 52 & 23 & 40 & 1303 & 1303 & 702 & 601 & 693 \\
\hline Bezostaja & 54 & 44 & 20 & 33 & 1001 & 1001 & 502 & 498 & 561 \\
\hline Litvanya (İthal) & 54 & 50 & 24 & 40 & 1097 & 1097 & 524 & 573 & 646 \\
\hline Adana-99 & 82 & 45 & 22 & 34 & 1451 & 1451 & 914 & 537 & 572 \\
\hline Sibirya (İthal) & 80 & 54 & 51 & 41 & 1890 & 322 & 643 & 804 & 675 \\
\hline
\end{tabular}


Çizelge 8. Ü̧̧ Farklı Metotla Kırılmış Altı Çeşit Buğday Numunesinin (Pandas, Bezostaja, Adana-99, Litvanya, Sibirya, Rus) Ekstensograf 135. D Maksimum Direnç Değerleri İle Glutopik Maksimum Pik Süresi Arasındaki Korelasyon İlişkisi

\begin{tabular}{lc}
\hline Un Örneği & Maksimum Pik Süresi \\
\hline Tavlı & 0.74 \\
Tavsız & 0.28 \\
Tam Buğday & 0.44 \\
\hline *P $<0.05$ seviyesinde önemli, **P<0.01 seviyesinde önemli
\end{tabular}

\subsubsection{Glutopik Cihazı Parametrelerinin Farinograf Su Absorbsiyon ve Düşme Sayısı Değerleri ile Karşılaş̧tırılması}

Tam buğday unu şeklinde öğ̈̆tülmüş numuneler dışında tavlı ve tavsız olarak öğ̈̈tülen buğday örneklerine ait unların su absorbsiyon değerleri ile Maksimum Tork değerleri arasında önemli bir ilişki olduğu gözlenmiştir. Çizelge 9'da görüleceği üzere tavlanarak öğütülmüş buğday ununda en yüksek korelasyon ilişkisi Maksimum Tork ve Maksimum Tork $15 \mathrm{~s}$ sonrası parametrelerinde görülmüştür. Tavsız öğütülmüş buğday ununda yapılan analizde Maksimum Tork ve A(4-5) parametrelerinde, tam buğday unu olarak öğütülmüş buğday ununda yapılan analizlerde ise en yüksek korelasyon ilişkisi Maksimum Tork $15 \mathrm{~s}$ öncesi ile A(3-4) parametre değerlerinde görülmüştür. Netice olarak özellikle Maksimum Tork parametresi ile unun su absorbsiyon değeri hakkında daha kuvvetli bir şekilde bilgi sahibi olunabileceği öngörülmektedir (Çizelge 6). Wang ve ark. (2017), su absorbsyon değerleri benzer olan un numunelerinde yapılan analizlerde; un mukavemetinin artmasıyla birlikte maksimum pik zamanı ve maksimum pik noktasına kadar olan alan değerinin arttığını, maksimum torkta ise çok az değişiklik gözlemlendiğini bildirmişlerdir. Zawieja ve ark. (2020), farinograf su absorbsiyon değeri ile Glutopik maksimum tork değeri arasında $r=0.85$, maksimum pik süresi arasında $r=0.45$ düzeyinde korelasyon ilişkisi belirlemişlerdir.

Çizelge 9. Ü̧̧ Farklı Metotla Kırllmış Altı Çeşit Buğday Numunesinin (Pandas, Bezostaja, Adana-99, Litvanya, Sibirya, Rus) Farinograf Su Absorbsiyon Değerleri İle Glutopik Cihazı Parametreleri Arasindaki Korelasyon İlişkisi

\begin{tabular}{lccccccccc}
\hline Un Örneği & PMT & BEM & AM & PM & $\mathrm{A}(0-1)$ & $\mathrm{A}(1-2)$ & $\mathrm{A}(2-3)$ & $\mathrm{A}(3-4)$ & $\mathrm{A}(4-5)$ \\
\hline Tavlı & -0.41 & $0.93^{* *}$ & 0.59 & $0.97 * *$ & 0.36 & 0.27 & 0.45 & 0.73 & $0.84 *$ \\
Tavsız & 0.14 & $0.94 * *$ & 0.72 & $0.90^{* *}$ & -0.73 & -0.57 & 0.57 & $0.92^{* *}$ & $0.95^{* *}$ \\
Tam Buğday & 0.22 & 0.64 & 0.81 & 0.55 & 0.75 & $-0.79 *$ & -0.06 & 0.85 & 0.05
\end{tabular}

PMT: Maksimum pik süresi, BEM: Maksimum tork, AM: Maksimum torktan $15 \mathrm{~s}$ önceki tork değeri, PM: Maksimum torktan $15 \mathrm{~s}$ sonraki tork değeri, A(0-1): A0 ile $\mathrm{A} 1$ arası alan, $\mathrm{A}(1-2)$ : A1 ile A2 arası alan, $\mathrm{A}(2-3)$ : A2 ile A3 aras1 alan, A(3-4): A3 ile A4 aras1 alan, A(4-5): A4 ile A5 aras1 alan.

$* \mathrm{P}<0.05$ seviyesinde önemli, ${ }^{*} \mathrm{P}<0.01$ seviyesinde önemli.

Düşme sayısı ile aynı numunelerin Glutopik analiz parametreleri değerleri karşılaştırılmış, sonuçlar Çizelge 6'da verilmiş ve sadece tavlanarak öğütülmüş buğday unu numunelerinde Çizelge 10 'da görüleceği üzere, düşme sayısı değeriyle $\mathrm{A}(0-1)$ arasinda $\mathrm{r}=0.82 \quad(\mathrm{P}<0.05)$ düzeyinde korelasyon olduğu görülmüştür. Bu alan, hamurun su ile ilk temas bölgesi olup glutenin gelişmeye henüz başlamadığı ve sadece nișasta ile suyun birleșiminden oluşan kıvam yoğunluğunun bıçağa uyguladığı karşı kuvvet alanı olarak değerlendirilmiştir. Bunun, aynı değirmende öğütülmeleri nedeniyle zedelenmiş nişasta miktarları aynı düzeyde olduğu kabul edilen unlardaki amilaz aktivitesinin etkisini ortaya çıkardığı ve amilaz aktivitesi düşük yani düşme sayısı değeri yüksek olan çeşitlerin zedelenmiş nişastaya etkisinin az olması nedeniyle Glutopik $\mathrm{A}(0-1)$ parametre değeri ile aynı yönde ilişki içinde olduğu değerlendirilmiştir.

Çizelge 10. Üç Farklı Metotla Kırılmış Altı Çeşit Buğday Numunesinin Düşme Sayısı Değerleri İle Glutopik Cihazı Parametreleri Arasindaki Korelasyon İlişkisi

\begin{tabular}{lccccccccc}
\hline Un Örneği & PMT & BEM & AM & PM & $\mathrm{A}(0-1)$ & $\mathrm{A}(1-2)$ & $\mathrm{A}(2-3)$ & $\mathrm{A}(3-4)$ & $\mathrm{A}(4-5)$ \\
\hline Tavlı & -0.38 & -0.12 & -0.33 & 0.02 & $0.82^{*}$ & 0.80 & -0.50 & -0.31 & 0.38 \\
Tavsız & -0.42 & 0.14 & -0.20 & -0.25 & 0.56 & 0.28 & -0.27 & -0.11 & -0.07 \\
Tam Buğday & -0.25 & -0.22 & -0.28 & -0.44 & -0.17 & 0.36 & 0.33 & -0.44 & -0.51 \\
\hline PMT:
\end{tabular}

PMT: Maksimum pik süresi, BEM: Maksimum tork, AM: Maksimum torktan $15 \mathrm{~s}$ önceki tork değeri, PM: Maksimum torktan 15 s sonraki tork değeri, A(0-1): A0 ile $\mathrm{A} 1$ arasi alan, $\mathrm{A}(1-2)$ : $\mathrm{A} 1$ ile $\mathrm{A} 2$ arasi alan, $\mathrm{A}(2-3)$ : $\mathrm{A} 2$ ile $\mathrm{A} 3$ aras1 alan, $\mathrm{A}(3-4)$ : $\mathrm{A} 3$ ile $\mathrm{A} 4$ aras1 alan, $\mathrm{A}(4-5)$ : $\mathrm{A} 4$ ile $\mathrm{A} 5$ arasi alan.

$* \mathrm{P}<0.05$ seviyesinde önemli, $* * \mathrm{P}<0.01$ seviyesinde önemli. 
Özetlenecek olursa (Çizelge 7); buğdaylarda maksimum pik süresi ile gluten miktarı arasında negatif, gluten indeks değeri arasında pozitif yönde bir korelasyon olduğu görülmüştür. Ekstensograf analizi 135. dakikadaki hamur uzama kabiliyetinin tavlı, tavsız öğütülmüş un ve çekiçli değirmende öğütülmüş tam buğday unu numunelerinde önemli sayılabilecek ilişkisinin A(34) değeri, maksimum tork ve maksimum tork sonrası tork değerleri ile olduğu görülmüşsür. Ekstensograf maksimum direnç değerleri ile Glutopik parametreleri arasında ilişkinin zayıf olduğu görülmüştür. Farinograf su absorbsiyon değerleri ile Glutopik parametreleri arasında yapılan değerlendirmede, su absorbsiyonunun özellikle maksimum tork değeri ile pozitif korelasyonunun olduğu gözlenmiştir. Glutopik verilerinin düşme sayısı değeri ile olan ilişkisine bakıldığında, sadece tavlanarak öğütülmüş buğday ununda $\mathrm{A}(0-1)$ parametre değeri ile düşme sayısı arasında bir ilişkinin olduğu görülmüştür.

Çalışmadan elde edilen bulgularla genel olarak uyumlu bir biçimde Brunnbauer ve ark. (2012); 9 buğday çeşidini Glutopik cihazıyla analize tabi tuttukları çalışmalarında; maksimum pik süresi değerinin hamur gelişme süresi ile $r=0.735$, maksimum tork ile protein miktarı arasında 0.956 , uzama kabiliyeti arasında 0.664, ekmek hacmi arasında 0.768 değerinde ilişki bulunduğunu, sonuçların protein içeriği ve ekmek hacmi ile yüksek korelasyon gösterdiğini, bununla birlikte zayıf ekmeklik özelliklere sahip bazı buğday çeşitlerinin bu korelasyonlara uymadığını bildirmişlerdir. Marti ve ark. (2014), Glutopik çalışmasında, protein içeriği ve maksimum pik arasında anlamlı bir pozitif korelasyon $(r=0.70, P<0.01)$ ilişkisinin gözlendiğini, pikin altındaki alan ve gluten arasında pozitif korelasyon değerine ulaşıldığını $(\mathrm{r}=0.76, \mathrm{P}<0.01)$ bildirmişlerdir. Söz konusu araştırıcılar ayrıca, Glutopik testinde, iyi kalitedeki buğdayların alanının $2400 \mathrm{AU}$ değerinden büyük olmasıyla numunelerin kalitesiz olanlardan (alan<2400 AU) ayrrt edilebildiğini bildirmişlerdir. Wang ve ark. (2018) Glutopik test cihazının, tam buğday unlarında gluten oluşumunun değerlendirilmesinde etkin biçimde kullanılabileceğini; Karaduman ve ark. (2019) Glutopik Maksimum Tork değerinin buğday genotiplerinin protein kalitesini ayırt etmek için yararlı bir parametre olduğunu bildirmişlerdir. Araştırıcılar, Sissons (2016)'nn bildirimiyle de uyumlu olarak Maksimum Tork ve Maksimum Tork $15 \mathrm{~s}$ sonrası tork değeri ile orta, zayıf ve çok zayıf un gruplarının açıkça birbirinden ayırt edilebildiğini ve söz konusu değerlerin tam buğday unlarındaki gluten'in kuvvetiyle yüksek oranda korelasyon gösterdiğini ifade etmişlerdir. Wang ve ark. (2017), Glutopik kuvvet indeksinin, pik maksimum alan ve zaman, pik maksimum tork, ekstensograf maksimum direnç ve alan, farinograf stabilite ve yoğurma tolerans indeksi gibi unhamur mukavemet parametreleri ile önemli korelasyonlar ( $\mathrm{P}$ $<0.05$ ) sergilediğini ifade etmişlerdir.

\section{2. İkinci Kısım Analizler}

Çalışmanın bu bölümünde Glutopik cihazı parametreleri hakkında edinilen bilgiler ışığında TS 2974 Buğday standardı (TSE, 2018) ve bu doğrultuda hazırlanmış 2018 yılı TMO Alım Baremine göre yapılan sinıflandırma ile Farinograf ve Ekstensograf değerleri karşılaştırılmıştır. İkinci kısım Glutopik analizlerinde, üretici firma mevcut yazılımı güncellemiş ve yeni yazılımın kullanımını tavsiye etmiştir. Analizlere ait veriler Çizelge 11'de sunulmuştur.

Çizelge 12'nin incelenmesiyle de görülebileceği gibi, protein miktarı ile en yüksek korelasyon ilişkisinin tavsız ve tavlı ögütülmüş unda $\mathrm{r}=0.67(\mathrm{P}<0.01)$ düzeyinde Maksimum
Tork parametresi ile; protein miktarı ile tam buğday unu olarak ögütülmüş numunelerde ise en yüksek korelasyonun $r=0.65$ $(\mathrm{P}<0.05)$ düzeyinde Toplanma enerjisi arasında olduğu görülmüştür. Özellikle Anadolu Beyaz Sert ve Anadolu Kırmızı Sert grubundaki buğdaylar ile korelasyon ilişkisinin $r=0.70$ 0.84 aralığında $(\mathrm{P}<0.01)$ olduğu görülmüsştür.

Brunnbauer ve ark. (2012)'nın yapmış olduğu çalışmada maksimum tork ile protein arasinda $\mathrm{r}=0.956$ oranında bir korelasyon ilişkisi olduğu belirlenmiş, Marti ve ark. (2014)'nın yapmış olduğu çalışmada ise protein içeriği ve maksimum tork arasında anlamlı bir pozitif korelasyon $(\mathrm{r}=0.70, \mathrm{P}<0.01)$ gözlendiği belirtilmiştir. Benzer biçimde Amoriello ve ark. (2016), Glutopik cihazının unun protein içeriğini değerlendirmede yararlı bir araç olduğunu bildirmişlerdir. $\mathrm{Bu}$ sonuçlar ile çalışmadan elde edilen bulguların nispeten uyumlu olduğu görülmüştür. Protein miktarının fazla olmasının cihazın bıçağının çevirme gücüne karşı oluşan tepki gücünün yani torkun artmasına neden olduğu düşünülmektedir.

Glutopik cihazından elde edilen verilerin Ekstensograf parametreleri ile olan ilişkisi incelendiğinde (Çizelge 13); özellikle 135. d çizim parametrelerinden enerji değeri ile tavsız ögütülmüş numunelerde maksimum pik süresinin $\mathrm{r}=0.78$ $(\mathrm{P}<0.01)$, tavlı ögütülmüş numunede $\mathrm{r}=0.51(\mathrm{P}<0.01)$ ve tam buğday unu olarak öğütülmüş numunede $r=0.60 \quad(\mathrm{P}<0.01)$ düzeyinde önemli bir ilişkinin olduğu görülmüştür. Bu bulgular, gerek uzama yeteneğinin ve gerekse maksimum direnç değerinin PMT ile olan ilşkisi konusunda bize fikir vermekte olup, gluten gelişim süresi ve dönme kuvvetine karşı oluşan mukavametin süresinin PMT parametre değerini belirlediği düşüncesi ile örtüşmektedir. Tam buğday unu olarak öğütülmüş numunelerde başlangıç enerjisi ile Ekstensograf 135. $d$ enerji değeri arasında $r$ $=0.78(\mathrm{P}<0.01)$, maksimum direnç arasında $\mathrm{r}=0.69(\mathrm{P}<0.01)$ düzeyinde bir ilişki olduğu görülmüştür. Uzama yeteneği ile birinci kısma göre ikinci kısımda yapılan çalı̧̧mada Glutopik parametreleri ile daha zayıf bir ilişki olduğu görülmüss, özellikle Ekstensograf enerji değeri ile daha kuvvetli bir ilişki olduğu tespit edilmiştir. Birinci kısımda yapmış olduğumuz çalışmada da maksimum direnç ile Glutopik değerleri arasında ilişki olmadığı görülmüştür.

Elde edilen verilerin genel olarak incelenmesiyle; tavlı ve tavsız ögütülen numuneler ile Glutopik parametrelerinin korelasyon ilişkisinin tam buğday unu ile öğütülmüş numunelere göre daha az olduğu görülmüsstür. Birinci kısımda yapmış olduğumuz çalışmada ise daha çok tavlı öğütülmüş numunelerde korelasyon ilişkisinin gerek su absorbsiyon değeri ile gerekse Ekstensograf uzama kabiliyeti ile daha iyi olduğu izlenmiştir. Lu ve Seetharaman (2014), genellikle sert buğday unları ile yapılan glutopik çizimlerinin yumuşak buğday unları ile yapılan çizimlere göre daha uzun PMT ve daha yüksek BEM değerine sahip olduğunu bildirmişlerdir.

Farinograf su absorbsiyon değeri ile Glutopik değerleri karşılaştırıldığında, birinci kısımda yapmış olduğumuz çalışmaya benzer olarak, tavlı öğütülmüş buğday ununda maksimum tork ile $\mathrm{r}=0.80(\mathrm{P}<0.01)$ düzeyinde pozitif yönde bir korelasyon olduğu görülmüştür. Analiz metoduna bakıldığında standart olarak bir hacim alanda rutubet değerine göre verilen su miktarının, glutenin su absorbsiyon yeteneğine göre oluşumu sırasında ortamdaki su miktarını azalttığı, bununda dönen bıçağa karşı oluşan kuvveti yani oluşan maksimum torku arttırdığı kanısına varılmışıtır. Ayrıca Başlangıç enerjisi ile $r=0.73$ $(\mathrm{P}<0.01)$ düzeyinde bir ilişki olduğu, Maksimum pik süresi ile $\mathrm{r}$ 
$=-0.62(\mathrm{P}<0.01)$ düzeyinde negatif yönde bir ilişkinin olduğu, bunun dişında kalan diğer Farinograf parametreleri ile Glutopik değerleri arasında çok fazla (anlamlı) bir ilişki olmadığı görülmüştür (Çizelge 13). Benzer biçimde Şanal ve ark. (2018) Farinograf su absorbsiyon değeri ile Glutopik maksimum pik süresi arasında negatif yönde bir korelasyon $(\mathrm{r}=-0.25)$ olduğunu bildirmiş̧lerdir.

Özetle Glutopik başlangıç enerjisi ile Ekstensograf uzama kabiliyeti ve enerji değerleri arasında, Farinograf su absorbsiyon düzeyi ile Glutopik maksimum tork ve başlangıç enerjisi arasında bir korelasyon olduğu görülmüştür. Bu çalışmadan elde edilen bulgularla uyumlu olarak Marti ve ark. (2015); GlutoPeak cihazının un kalitesini ortaya koyan hızlı bir test cihazı olarak potansiyel gösterilsede, literatür çalışmalarında kullanılan farklı yazılımlar ve bu çerçevede farklı test koşullarının (yani un-su oranı ve karıştırma hızı) bu cihazdan elde edilen sonuçların birbirleriyle karşılaştırılmasını güçleştirdiğini bildirmişlerdir. 


\section{European Journal of Science and Technology}

\begin{tabular}{|c|c|c|c|c|c|c|c|c|c|c|c|c|c|c|c|c|c|c|c|c|c|c|c|c|c|c|c|c|c|c|c|c|c|c|}
\hline ż & 胥 & 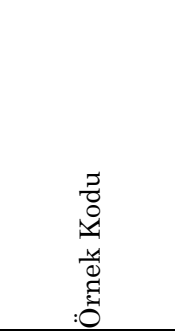 & 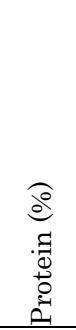 & 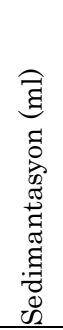 & 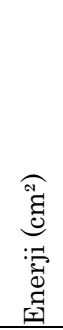 & 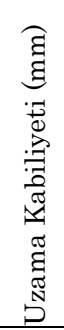 & 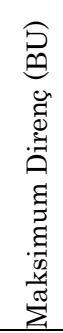 & 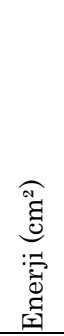 & 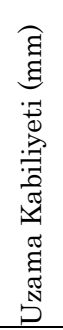 & 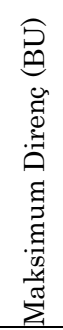 & 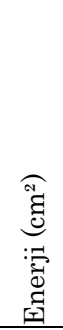 & 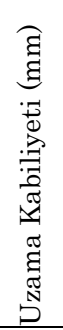 & 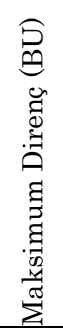 & $\begin{array}{l}\text { (1) } \\
\sum_{i=1}\end{array}$ & 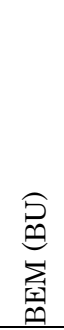 & $\begin{array}{l}\hat{\rho} \\
\sum_{i}^{e}\end{array}$ & $\begin{array}{l}\hat{D} \\
\sum_{\Omega}^{n}\end{array}$ & 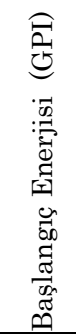 & 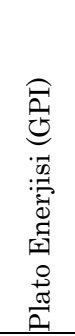 & 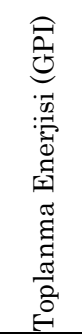 & $\begin{array}{l}\text { (n) } \\
\sum_{i}\end{array}$ & 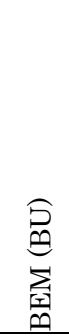 & $\begin{array}{l}\hat{D} \\
\sum_{i}^{\infty}\end{array}$ & $\begin{array}{l}\hat{D} \\
\sum_{a}^{n}\end{array}$ & 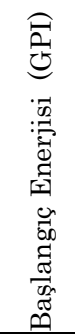 & 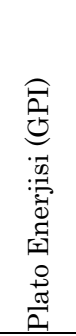 & 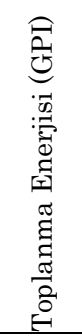 & $\begin{array}{l}\text { (1) } \\
\sum_{i}^{E}\end{array}$ & $\sum_{\substack{n \\
\oplus}}^{\rho}$ & $\begin{array}{l}\hat{\rho} \\
\sum \\
\sum\end{array}$ & $\begin{array}{l}\hat{D} \\
\sum_{\Delta}^{0}\end{array}$ & 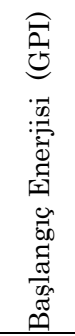 & 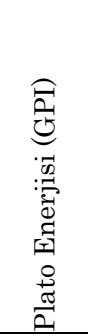 & 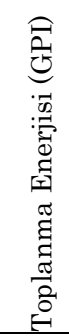 \\
\hline 1 & $\mathrm{ABS}$ & $2 \mathrm{CYH}-\mathrm{ABS}-3$ & 11.6 & 35 & 108 & 155 & 515 & 134 & 144 & 716 & 141 & 136 & 832 & 59 & 47 & 27 & 39 & 1395 & 1395 & 1236 & 62 & 44 & 20 & 39 & 103 & 111 & 1174 & 71 & 43 & 22 & 33 & 1240 & 1240 & 1062 \\
\hline 3 & AKS & SKT-AKS-2 & 12.9 & 35 & 67 & 139 & 344 & 71 & 130 & 399 & 77 & 126 & 461 & 45 & 53 & 23 & 43 & 1101 & 1101 & 1337 & 61 & 49 & 31 & 40 & 1175 & 147 & 1368 & 57 & 44 & 18 & 33 & 957 & 957 & 1053 \\
\hline 4 & DB & VAF-DB-1 & 14 & 24 & 67 & 130 & 367 & 70 & 126 & 410 & 70 & 122 & 431 & 42 & 52 & 23 & 37 & 1010 & 1010 & 1235 & 60 & 48 & 26 & 36 & 1312 & 1312 & 1243 & 56 & 40 & 20 & 32 & 961 & 961 & 1016 \\
\hline 5 & DK & PHV-DK-4 & 11.4 & 31 & 63 & 134 & 338 & 64 & 111 & 424 & 71 & 117 & 455 & 37 & 51 & 24 & 40 & 964 & 964 & 1288 & 62 & 44 & 20 & 39 & 103 & 111 & 1174 & 49 & 42 & 18 & 32 & 812 & 812 & 963 \\
\hline 6 & $\mathrm{DB}$ & VAF-DB-4 & 11.7 & 29 & 68 & 132 & 365 & 71 & 118 & 451 & 64 & 108 & 449 & 49 & 47 & 21 & 36 & 1045 & 1045 & 1137 & 70 & 45 & 19 & 35 & 178 & 57 & 1107 & 61 & 39 & 17 & 27 & 916 & 916 & 911 \\
\hline 7 & AKS & ESP-AKS-2 & 13.1 & 40 & 110 & 157 & 526 & 112 & 144 & 605 & 110 & 136 & 624 & 71 & 54 & 46 & 44 & 1937 & 1937 & 1494 & 101 & 44 & 28 & 42 & 100 & 333 & 1269 & 63 & 45 & 20 & 35 & 1101 & 1101 & 1093 \\
\hline 8 & AKS & SKT-AKS-1 & 13.6 & 36 & 71 & 142 & 371 & 79 & 133 & 440 & 85 & 130 & 499 & 68 & 48 & 35 & 38 & 156 & 28 & 1359 & 71 & 49 & 45 & 41 & 1227 & 338 & 1396 & 51 & 50 & 20 & 37 & 1026 & 1026 & 1221 \\
\hline 9 & AKS & SKT-AKS-4 & 11.3 & 28 & 79 & 135 & 437 & 97 & 116 & 642 & 101 & 109 & 730 & 40 & 47 & 26 & 37 & 1012 & 1012 & 1183 & 91 & 43 & 24 & 36 & 196 & 39 & 1180 & 62 & 42 & 18 & 33 & 963 & 963 & 1014 \\
\hline 10 & AKS & ESP-AKS-3 & 12.6 & 39 & 94 & 151 & 459 & 111 & 141 & 617 & 111 & 128 & 679 & 70 & 51 & 27 & 42 & 1567 & 1567 & 1312 & 87 & 47 & 26 & 40 & 170 & 178 & 1264 & 60 & 42 & 23 & 32 & 1104 & 1104 & 1052 \\
\hline 12 & DB & VAF-DB-3 & 12 & 25 & 62 & 132 & 332 & 69 & 123 & 408 & 64 & 116 & 406 & 49 & 43 & 19 & 34 & 955 & 655 & 1050 & 60 & 45 & 20 & 34 & 1162 & 1162 & 1104 & 57 & 39 & 18 & 28 & 908 & 908 & 923 \\
\hline 13 & DK & PHV2-DK-2 & 13 & 34 & 61 & 133 & 324 & 68 & 124 & 399 & 75 & 117 & 471 & 34 & 56 & 30 & 43 & 1047 & 1047 & 1432 & 37 & 47 & 22 & 42 & 859 & 859 & 1219 & 38 & 42 & 19 & 31 & 744 & 744 & 1018 \\
\hline 14 & DB & VAF-DB-2 & 13.1 & 30 & 67 & 127 & 386 & 85 & 129 & 488 & 83 & 125 & 504 & 42 & 49 & 22 & 36 & 952 & 952 & 1166 & 40 & 49 & 27 & 36 & 1083 & 1083 & 1241 & 58 & 41 & 18 & 31 & 923 & 923 & 997 \\
\hline 15 & ABS & CYH-ABS-1 & 13.6 & 42 & 130 & 164 & 603 & 155 & 150 & 823 & 147 & 135 & 887 & 70 & 51 & 33 & 41 & 1706 & 1706 & 1384 & 58 & 48 & 29 & 42 & 327 & 90 & 1363 & 72 & 46 & 22 & 35 & 1262 & 1262 & 1122 \\
\hline 16 & AKS & ESP-AKS-1 & 15 & 61 & 132 & 184 & 551 & 143 & 162 & 698 & 155 & 159 & 785 & 72 & 60 & 59 & 50 & 1751 & 233 & 1698 & 100 & 51 & 50 & 44 & 124 & 125 & 1461 & 61 & 53 & 24 & 42 & 1307 & 1307 & 1366 \\
\hline 17 & AKS & RML-AKS-3 & 12.2 & 35 & 84 & 126 & 495 & 97 & 105 & 732 & 105 & 98 & 868 & 49 & 45 & 26 & 44 & 1196 & 1196 & 1226 & 70 & 50 & 27 & 42 & 1598 & 1598 & 1351 & 73 & 38 & 26 & 34 & 1318 & 1318 & 1048 \\
\hline 18 & AKS & RML-AKS-2 & 12.9 & 40 & 97 & 138 & 531 & 118 & 117 & 796 & 121 & 114 & 864 & 50 & 52 & 30 & 45 & 1318 & 1318 & 1306 & 55 & 50 & 36 & 42 & 1625 & 1625 & 1382 & 65 & 44 & 26 & 35 & 1290 & 1290 & 1118 \\
\hline
\end{tabular}


45. $\mathrm{d}$ 90. d
Tavsız öğütülmüş un
Tavlı öğütülmüş un
Tam buğday unu

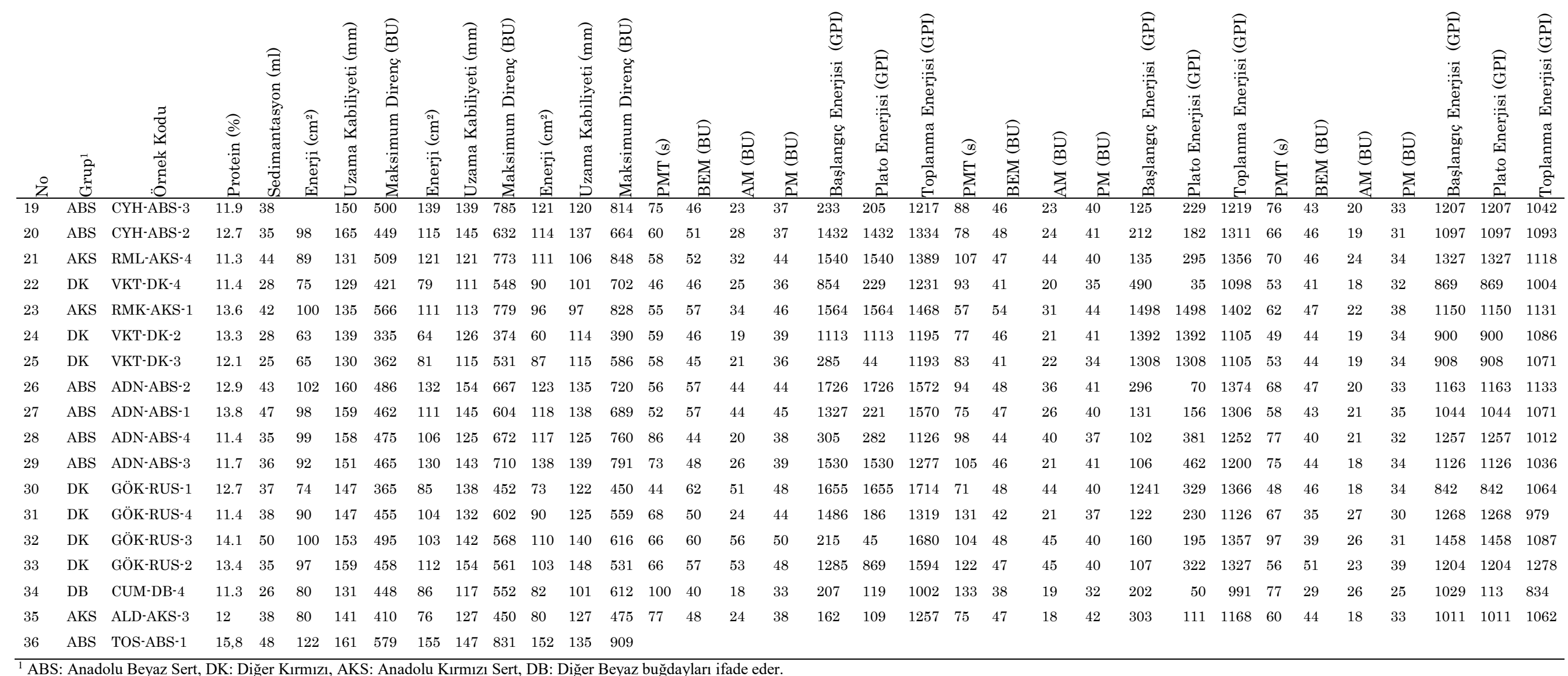
alan, A(3-4): A3 ile A4 arası alan, A(4-5): A4 ile A5 arası alan. 
European Journal of Science and Technology

Çizelge 12. Ü̧̧ Farkll Şekilde Öğ̈̈tülen Örneklerin Glutopik Analiz Sonuçları İle Teknolojik Analiz Değerlerinin Korelasyon İlişkisi

\begin{tabular}{|c|c|c|c|c|c|c|c|c|c|c|c|c|c|c|c|c|c|c|c|c|c|}
\hline Öğütme Türü & & & Tavsiz & öğütül & üş Un & & & & & Tavlı & öğütülm & aüş un & & & & & Tam & buğday & unu & & \\
\hline $\begin{array}{l}\text { Teknolojik } \\
\text { Analizler }\end{array}$ & 党 & 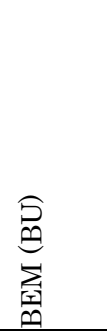 & $\begin{array}{l}\hat{S}_{4} \\
\sum_{4}^{1}\end{array}$ & 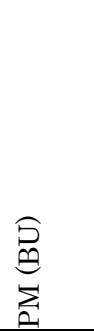 & 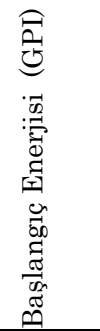 & 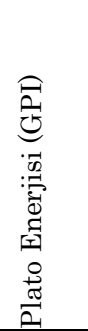 & 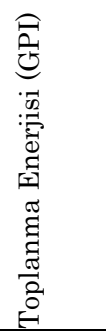 & 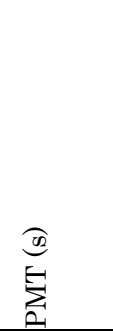 & $\sum_{\substack{n \\
n}}^{\stackrel{D}{n}}$ & $\begin{array}{l}S \\
\sum_{i}\end{array}$ & 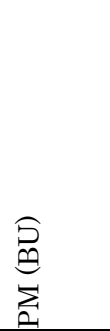 & 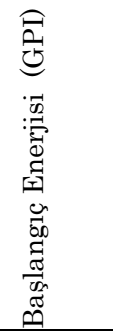 & 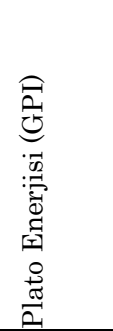 & 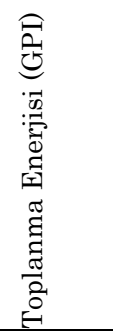 & 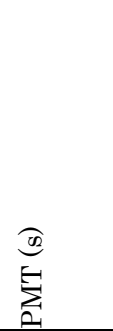 & 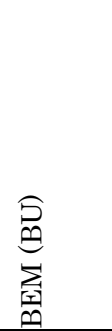 & $\begin{array}{l}S_{0} \\
\sum_{4}^{\circ}\end{array}$ & $\begin{array}{l}\hat{D}_{2} \\
\sum_{a}\end{array}$ & 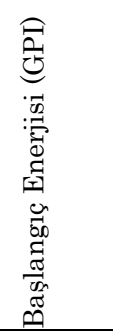 & 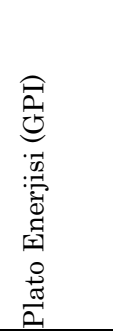 & 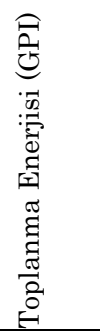 \\
\hline Protein & -0.07 & $0.67 * *$ & $0.63^{* *}$ & $0.56^{*}$ & 0.23 & 0.05 & $0.65^{* *}$ & -0.30 & $0.67^{* *}$ & $0.49^{* *}$ & $0.54^{* *}$ & 0.23 & 0.18 & $0.64^{* * *}$ & -0.12 & $0.52^{* *}$ & 0.14 & $0.57^{* *}$ & 0.14 & 0.25 & $0.65^{* *}$ \\
\hline Sedimantasyon & 0.29 & $0.66^{* *}$ & $0.75^{* *}$ & $0.76^{*}$ & $0.37^{*}$ & 0.04 & $0.75^{*}$ & 0.34 & $0.53^{* *}$ & $0.64^{* * *}$ & $0.70^{* *}$ & $-0.34^{*}$ & -0.31 & $0.73^{* *}$ & $0.36^{*}$ & $0.48^{* *}$ & $0.47^{* * *}$ & $0.58^{* *}$ & $0.65^{* *}$ & $0.63^{* *}$ & $0.67 * *$ \\
\hline $\begin{array}{l}\text { Gecikmeli } \\
\text { Sedimantasyon }\end{array}$ & 0.18 & $0.67^{* *}$ & $0.71^{* *}$ & $0.78^{*}$ & $0.39 *$ & 0.10 & $0.75^{*}$ & $0.41^{*}$ & $0.45^{* * *}$ & $0.58^{* * *}$ & $0.64^{* *}$ & -0.25 & -0.18 & $0.66^{* *}$ & 0.32 & $0.46^{* *}$ & $0.46^{* *}$ & $0.55^{* *}$ & $0.60^{* *}$ & $0.61^{* *}$ & $0.63^{* *}$ \\
\hline Gluten Miktarı & $0.43^{*}$ & $0.43^{*}$ & $0.40^{*}$ & 0.23 & -0.06 & -0.12 & $0.39 *$ & $-0.37^{*}$ & $0.54^{* *}$ & $0.44^{*}$ & 0.32 & 0.20 & 0.06 & $0.49^{* * *}$ & -0.26 & $0.52^{* *}$ & -0.24 & $0.45^{* *}$ & -0.11 & 0.15 & $0.51 * *$ \\
\hline Gluten İndeks & $-0.44^{*}$ & 0.00 & 0.07 & 0.15 & 0.30 & 0.16 & 0.04 & $0.52^{* *}$ & -0.11 & 0.04 & 0.07 & $-0.34^{*}$ & -0.21 & 0.02 & $0.44^{* *}$ & -0.06 & $0.41^{*}$ & 0.07 & $0.50^{* *}$ & 0.32 & 0.06 \\
\hline Düşme Sayısı & -0.44 & -0.32 & $-0.55^{* *}$ & -0.43 & -0.25 & -0.01 & $-0.49^{*}$ & $-0.64^{* *}$ & 0.05 & -0.39 & -0.33 & $0.52^{* * *}$ & $0.66^{* *}$ & -0.27 & -0.37 & -0.23 & -0.35 & -0.19 & $-0.49^{*}$ & -0.30 & -0.35 \\
\hline str & -0.01 & 0.29 & 0.26 & 0.17 & -0.14 & -0.30 & 0.33 & -0.07 & -0.28 & 0.07 & -0.10 & 0.00 & -0.15 & -0.14 & -0.32 & 0.02 & -0.13 & -0.04 & $-0.36^{*}$ & -0.39 & 0.04 \\
\hline sn & 0.08 & -0.36 & -0.29 & -0.33 & 0.16 & 0.15 & $-0.40^{*}$ & 0.00 & 0.01 & -0.27 & -0.10 & -0.17 & 0.02 & -0.07 & 0.17 & 0.06 & -0.07 & 0.09 & 0.16 & 0.13 & -0.01 \\
\hline relax & -0.04 & 0.37 & 0.31 & 0.30 & -0.12 & -0.24 & $0.42^{*}$ & 0.00 & -0.24 & 0.13 & -0.02 & 0.03 & -0.13 & -0.11 & -0.27 & -0.07 & -0.05 & -0.11 & -0.32 & -0.34 & -0.03 \\
\hline
\end{tabular}

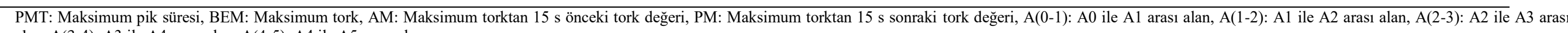
alan, A(3-4): A3 ile A4 arasi alan, A(4-5): A4 ile A5 arasi alan.

${ }^{*} \mathrm{P}<0.05$ seviyesinde önemli, ${ }^{* * \mathrm{P}<0.01}$ seviyesinde önemli. 
Avrupa Bilim ve Teknoloji Dergisi

Çizelge 13. Farklı Metotlarla Öğ̈̈tülmüs Numuneler İle Yapılan Glutopik Analizleriyle Ekstensograf Ve Farinograf Verileri Arasindaki Korelasyon Değerleri

\begin{tabular}{|c|c|c|c|c|c|c|c|c|c|c|c|c|c|c|c|c|}
\hline & & \multicolumn{3}{|c|}{ 45. d } & \multicolumn{3}{|c|}{ 90. d } & \multicolumn{3}{|c|}{ 135. d } & \multicolumn{6}{|c|}{ Farinograf ölçümleri } \\
\hline & & 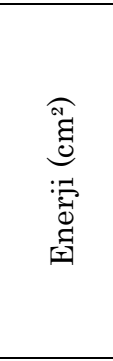 & 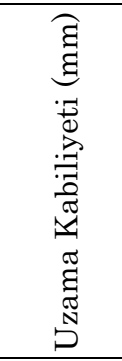 & 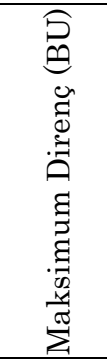 & 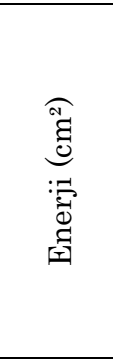 & 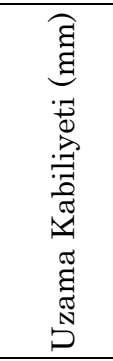 & 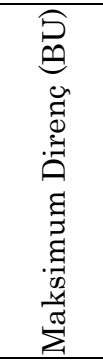 & 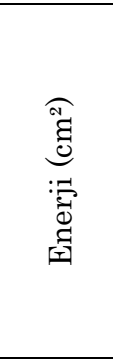 & 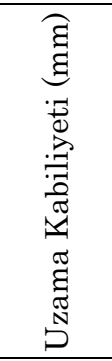 & 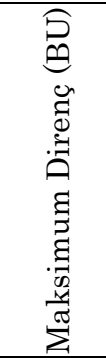 & 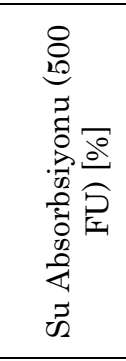 & 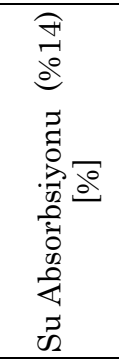 & 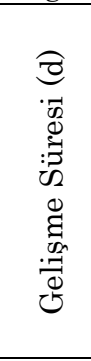 & 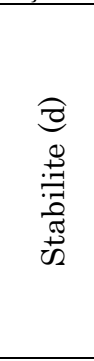 & 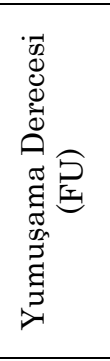 & 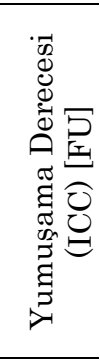 \\
\hline \multirow{7}{*}{ 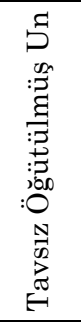 } & PMT (s) & $0.54^{* *}$ & $0.46^{* *}$ & $0.52^{* *}$ & $0.48^{* *}$ & 0.42 & $0.41^{*}$ & $0.78^{* *}$ & $0.37^{*}$ & $0.33^{*}$ & $-0.40^{*}$ & 0.16 & 0.13 & -0.10 & -0.06 & 0.01 \\
\hline & BEM (BU) & $0.34^{*}$ & $0.45^{* *}$ & -0.19 & -0.16 & $0.52^{* *}$ & -0.30 & -0.21 & $0.33^{*}$ & -0.26 & $0.45^{*}$ & 0.25 & 0.07 & 0.11 & -0.04 & 0.14 \\
\hline & $\mathrm{AM}(\mathrm{BU})$ & $0.56^{* *}$ & $0.62^{* *}$ & $-0.39^{*}$ & $-0.42^{*}$ & $0.65^{* *}$ & -0.24 & $-0.40^{*}$ & $0.52^{* *}$ & -0.23 & 0.20 & 0.32 & 0.13 & -0.01 & -0.13 & 0.15 \\
\hline & PM (BU) & $0.47^{* *}$ & $0.45^{* *}$ & -0.16 & $0.34^{*}$ & $0.41^{*}$ & -0.02 & 0.03 & 0.23 & 0.00 & 0.33 & 0.08 & 0.03 & 0.21 & -0.03 & 0.04 \\
\hline & Başlangıç Enerjisi（GPI） & $0.47^{* * *}$ & $0.36^{* *}$ & -0.29 & $0.43^{* *}$ & $0.38^{*}$ & 0.02 & $0.35 *$ & 0.28 & 0.03 & 0.09 & 0.15 & 0.20 & -0.06 & -0.16 & 0.03 \\
\hline & Plato Enerjisi (GPI) & 0.28 & 0.19 & -0.19 & 0.20 & 0.23 & 0.11 & 0.16 & 0.20 & 0.14 & 0.14 & -0.11 & 0.05 & -0.03 & -0.03 & -0.06 \\
\hline & Toplanma Enerjisi (GPI) & $0.46^{* *}$ & $0.57^{* *}$ & -0.15 & $-0.35^{*}$ & $0.60^{* *}$ & -0.27 & -0.13 & $0.40^{*}$ & -0.22 & 0.26 & 0.27 & 0.08 & 0.09 & -0.03 & 0.15 \\
\hline \multirow{7}{*}{ 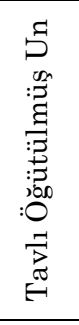 } & PMT (s) & 0.48 & $0.45^{* *}$ & $0.45^{* *}$ & $0.49 * *$ & 0.43 & $0.43^{*}$ & $0.51^{* *}$ & $0.36^{*}$ & $0.39 *$ & $-0.62^{* *}$ & $-0.59 * *$ & -0.11 & $0.43^{*}$ & 0.05 & -0.30 \\
\hline & BEM (BU) & 0.15 & 0.28 & -0.02 & 0.13 & 0.23 & 0.04 & & 0.21 & 0.03 & $0.80 * *$ & $0.82^{* *}$ & 0.44 & -0.28 & -0.24 & 0.38 \\
\hline & $\mathrm{AM}(\mathrm{BU})$ & $0.50^{* *}$ & $0.47^{* *}$ & $-0.41^{*}$ & $0.42^{*}$ & $0.44^{* *}$ & 0.00 & $0.44^{* *}$ & $0.42^{*}$ & -0.07 & 0.51 & $0.51^{*}$ & 0.12 & -0.01 & -0.18 & 0.14 \\
\hline & PM (BU) & $0.49^{* *}$ & $0.49^{* *}$ & $0.42^{*}$ & $0.44^{* *}$ & $0.42^{*}$ & $0.35^{*}$ & $0.42^{*}$ & 0.35 & $0.35^{*}$ & 0.25 & 0.22 & 0.21 & 0.00 & -0.01 & 0.20 \\
\hline & Başlangıç Enerjisi (GPI) & $-0.47^{* *}$ & $-0.53^{* *}$ & -0.13 & $-45^{* *}$ & $-0.45^{* *}$ & 0.16 & $-0.46^{* *}$ & $-0.42^{*}$ & 0.19 & $0.73^{* *}$ & $0.73^{* *}$ & 0.05 & -0.13 & -0.12 & 0.24 \\
\hline & Plato Enerjisi (GPI) & $-0.35^{*}$ & $-0.48^{* *}$ & -0.07 & 0.13 & $-0.44^{* *}$ & 0.29 & 0.07 & $-0.41^{*}$ & 0.28 & $0.59^{* *}$ & $0.53^{* *}$ & 0.12 & -0.18 & -0.17 & 0.28 \\
\hline & Toplanma Enerjisi (GPI) & $0.56^{* *}$ & 0.49 & $-0.50 * *$ & $0.52^{* *}$ & $0.45^{* *}$ & $0.43^{* * *}$ & $0.52^{* *}$ & $0.36^{*}$ & $0.43^{*}$ & $0.44^{*}$ & $0.60^{* *}$ & 0.36 & -0.19 & -0.22 & 0.36 \\
\hline \multirow{7}{*}{ 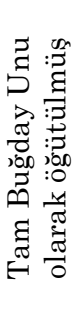 } & PMT (s) & $0.55^{* * *}$ & 0.65 & $0.64^{* *}$ & $0.58^{* *}$ & 0.62 & $0.62^{* *}$ & $0.60^{* *}$ & 0.57 & $0.56^{* *}$ & -0.38 & 0.07 & 0.29 & -0.22 & -0.15 & -0.02 \\
\hline & BEM (BU) & -0.05 & $0.49^{*}$ & -0.04 & -0.05 & $0.51^{* *}$ & -0.22 & -0.06 & $0.39^{*}$ & -0.19 & 0.34 & 0.34 & 0.23 & -0.12 & -0.14 & 0.27 \\
\hline & AM (BU) & $0.54^{* *}$ & 0.63 & $0.63^{* *}$ & $0.47^{* *}$ & 0.56 & $0.55^{* *}$ & $0.46^{* *}$ & 0.50 & $0.50^{* *}$ & 0.07 & 0.04 & 0.09 & 0.16 & -0.08 & -0.08 \\
\hline & PM (BU) & $0.47^{* *}$ & $0.47^{* *}$ & $0.39^{*}$ & $0.42^{*}$ & $0.39^{*}$ & $0.34^{* *}$ & $0.44^{* *}$ & $0.35^{*}$ & $0.34^{*}$ & 0.33 & 0.36 & 0.31 & -0.17 & -0.27 & 0.35 \\
\hline & Başlangıç Enerjisi (GPI) & $0.76^{* *}$ & $0.49^{* *}$ & $0.82^{* *}$ & $0.76^{* *}$ & $0.35^{*}$ & $0.77^{* * *}$ & $0.76^{* *}$ & $0.42^{*}$ & $0.69^{* *}$ & -0.13 & 0.17 & 0.27 & -0.07 & -0.17 & 0.00 \\
\hline & Plato Enerjisi (GPI) & $0.60^{* *}$ & $0.47^{* * *}$ & $0.59^{* *}$ & $0.62^{* *}$ & $0.37^{*}$ & $0.59^{* *}$ & $0.63^{* *}$ & $0.44^{* *}$ & $0.52^{* *}$ & -0.13 & 0.17 & 0.27 & -0.07 & -0.17 & 0.00 \\
\hline & Toplanma Enerjisi (GPI) & $0.54^{* *}$ & $0.60 * *$ & $-0.41^{*}$ & $0.48^{* *}$ & $0.57^{* *}$ & -0.11 & $0.50^{* * *}$ & $0.52^{* *}$ & -0.12 & 0.30 & 0.41 & 0.24 & -0.09 & -0.18 & 0.24 \\
\hline
\end{tabular}




\section{Sonuç}

Gerek Türkiye'de ve gerekse diğer ülkelerde Glutopik hakkında yeterli çalışma olmaması ve parametreleri hakkında net bilgilere ulaşılamamış olması nedeniyle, sonuçları bilinen numuneler üzerinde farklı ögütme tekniklerinin de etkisinin görülmesi amacıyla birinci ve ikinci kısım çalışma diye adlandırılan çalışmalar neticesinde cihazın parametreleri hakkında bilgi edinilmeye çalışılmıştır. Elde edilen verilerin incelenmesi ve birlikte değerlendirilmesiyle; özellikle tam buğday unu olarak öğütülmüş numunede protein miktarı ile birinci k1sımda maksimum tork ve $\mathrm{A}(3-4)$ parametresi ile ilişkinin kurulabildiği, ikinci kısımda ise yine maksimum tork ve toplanma enerjisi (A(3-5)) parametresi ile ilişki kurulabildiği, sedimantasyon değerleri ile maksimum tork ve toplanma enerjisi değerleri arasında bir ilişki olduğu görülmüştür. Birinci kısımda Glutopik parametreleri ile Ekstensograf uzama kabiliyeti arasında daha fazla ilişki kurulmuşken, ikinci kısımda Glutopik parametreleri ile daha çok Ekstensograf enerji değeri arasında ilişki kurulmuştur. Farinograf su absorbsiyon değeri ile maksimum tork arasında (her iki kısım çalışmada da aynı düzeyde) pozitif yönde ilişki olduğu görülmüştür. Maksimum direnç değeri ile Glutopik parametreleri arasında anlamlı bir ilişkiye rastlanılmamıştır.

Glutopik cihazının düşük numune miktarı ihtiyacı, kısa analiz süresi ve gluten yapısı hakkında bazı bilgiler vermiş olması olumlu bir yan olarak dururken, elde edilen verilerin değişkenliğinin çok ve parametrelerinin tam olarak anlamlandırılamamış olması halen cihaz ile daha fazla çalışma yapılması gerektiğini ortaya koymuştur. Bununla birlikte maksimum tork değeri yüksek olan buğdayların su absorbsiyonlarının yüksek olduğu, özellikle $\mathrm{A}(0-5)$ arası alan ve mesafenin büyümesine koşut olarak hamurun direnç ve uzamasının arttığı, elastikiyetinin geliştiği belirlenmiştir.

Glutopik analizi ve parametreleri ile öngörülen sınıflandırma çerçevesinde bazı değerlendirmeler yapılabileceği, ancak yapılan çalışmalarda birbirleriyle çelişen sonuçların olduğu, ayrıca halen yazılım çalışmalarının tam olarak neticelenmemiş olması cihazın parametreleri ile ilgili kuşkuların doğmasına sebep olmuştur. $\mathrm{Bu}$ itibar ile cihaz yazılımında verilen parametrelerin üretici firma tarafından gözden geçirilerek analiz esnasında çizilen grafikte, daha stabil sonuçlar verecek farklı parametrelerin üretilerek olgunlaştırılabileceği düşünülmektedir.

\section{Teșekkür}

Bu çalışma yüksek lisans tezinden üretilmiş olup, Osmaniye Korkut Ata Üniversitesi Bilimsel Araştırmalar Projeleri Birimi tarafindan OKÜBAP-2017-PT3-037 proje numarası ile desteklenmiştir.

\section{Kaynakça}

Amoriello, T., Turfani, V., Galli, V., Mellara, F. \& Carcea, M. (2016). Evaluation of new viscometer performance in predicting the technological quality of soft wheat flour. Cereal Chemistry, 93(4), 364-368.

Anonymus (2018). Use Gluten to Quickly Determine Quality, Using the GlutoPeak. https://www.brabender.com/food/produkte/rheometer/via- gluten-schnell-mehle-schrote-vital-gluten-qualifizierenglutopeak/\#. (Erişim tarihi: 25.01.2019).

Brunnbauer, M., Selmair, P. \& Köhler, P. (2012). Determination of the gluten aggregation behaviour from different wheat cultivars and correlation with the rheological and the baking properties. ISFRS 2012 Congress, 10-13 April 2012 (in Brabender Glutopeak inkl. Software Glutopeak book), Duisburg, Germany, p:171-172.

Chandi, G.K. \& Seetharaman, K. (2012). Optimization of gluten peak tester: a statistical approach. Journal of Food Quality, $35(1), 69-75$.

Çeliker, G. \& Dizlek, H. (2020). Ülkemizdeki buğday standardına göre aynı kategoride yer alan ekmeklik buğday çeşitlerinin reolojik özelliklerinin belirlenerek hububat alım kriterleriyle uyumluluğunun incelenmesi. Bursa Uludăg Üniversitesi Ziraat Fakültesi Dergisi, 34(1), 71-92.

Dizlek, H. \& Çeliker, G. (2017). Wheat purchase criterias of Soil Crops Office (TMO) in Turkey and examination of its suitability. $2^{\text {nd }}$ International Energy and Engineering Conference, 12-13 October 2017, Gaziantep, s:1231.

Dizlek, H. \& Özer, M.S. (2016). Effects of sunn pest (eurygaster integriceps) damage ratio on physical, chemical, and technological characteristics of wheat. Quality Assurance and Safety of Crops and Foods, 8(1), 145-156.

Elgün, A. \& Ertugay, Z. (1997). Tahıl İşleme Teknolojisi. Erzurum: Atatürk Üniversitesi Ziraat Fakültesi Ofset Tesisleri.

Greenaway, W.T., Neustadt, M.H. \& Zeleny, L. (1965). A test for stink bug damage in wheat. Cereal Chemistry, 42(6), 577579.

Karaduman, Y., Akın, A., Türkölmez, S. \& Tunca, Z.Ş. (2015). Ekmeklik buğday islah programlarında gluten kalitesinin değerlendirilmesi için glutopik parametrelerinin kullanılabilirliğinin araştırılması. Tarla Bitkileri Merkez Araştırma Enstitüsü Dergisi, 24(1), 65-74.

Karaduman, Y., Önder, O., Sayaslan, A. \& Aydın, N. (2019). Utilisation of glutopeak tester on whole-wheat flour for gluten quality assessment. Quality Assurance and Safety of Crops and Foods, 11(3), 295-304.

Lu, Z. \& Seetharaman, K. (2014). Suitability of Ontario-grown hard and soft wheat flour blends for noodle making. Cereal Chemistry, 91(5), 482-488.

Lukow, O.M., Payne, P. \& Tkauchuk, R. (1989). The HMW glutenin subunits composition of Canadian wheat cultivars and their association with bread-making quality. Journal of the Science of Food and Agriculture, 46, 451-460.

Malegori, C., Grassi, S., Ohm, J.B., Anderson, J. \& Marti, A. (2018). Glutopeak profile analysis for wheat classification: skipping the refinement process. Journal of Cereal Science, 79, 73-79.

Marti, A., Cecchini, C., D'egidio, M.G., Dreisoerner, J. \& Pagani, M.A. (2014). Characterization of durum wheat semolina by means of a rapid shear-based method. Cereal Chemistry, 91(6), 542-547.

Marti, A., Qiu, X., Schoenfuss, T.C. \& Seetharaman, K. (2015). Characteristics of Perennial Wheatgrass (Thinopyrum intermedium) and refined wheat flour blends: impact on rheological properties. Cereal Chemistry, 92(5), 434-440.

Melnyk, J.P. (2011). Effect of the hofmeister series on gluten aggregation measured using a high shear-based technique. Food Research International, 44, 893-896. 
Posner, E.S. \& Hibbs, A.N. (1997). Wheat Flour Milling. St. Paul, MN: American Association Cereal Chemists Incorporated.

Sissons, M. (2016). GlutoPeak: a breeding tool for screening dough properties of durum wheat semolina. Cereal Chemistry, 93(6), 550-556.

Şahin, M., Göçmen Akçacık, A., Aydoğan, S., Demir, B., Mecitoğlu Güçbilmez, Ç., Hamzaoğlu, S., Gür, S. \& Yıldırım, T. (2020) Ekmeklik buğday (Triticum aestivum) genotiplerinin gluten kalitesinin glutopik cihazı ile değerlendirilmesi. Harran Tarım ve Glda Bilimleri Dergisi, 24(2), 151-164.

Şanal, T., Evlice, A.K., Pehlivan, A. \& Külen, S. (2018). The relationship between some quality characteristics and glutopeak parameters in bread wheat. Proceedings of the $13^{\text {th }}$ International Gluten Workshop, 14-17 March 2018, Mexico.

TMO (2018). Toprak Mahsulleri Ofisi, Hububat Raporu, Ankara. TSE (2013a). Buğday - Sedimentasyon Endeksi Tayini - Zeleny Deneyi. TS EN ISO 5529, Ankara.

TSE (2013b). Buğday, Çavdar ve Bunların Unları, Durum Buğdayı ve Durum Buğdayı İrmiği - Hagberg - Pertene Göre Düşme Sayısının Tayini. TS EN ISO 3093, Ankara.

TSE (2015a). Tahıllar - Nem ve Protein Tayini - Bütün Tanelerde Yakın - Infrared - Spektroskopi Kullanma Metodu. TS EN 15948, Ankara.
TSE (2015b). Buğday Unu - Hamurun Fiziksel Karakteristikleri - Bölüm 1: Farinograf Kullanılarak Su Absorbsiyonunun ve Reolojik Özelliklerinin Tayini. TSE EN ISO 5530-1, Ankara.

TSE (2015c). Buğday Unu - Hamurun Fiziksel Karakteristikleri - Bölüm 2: Ekstensograf Kullanılarak Reolojik Özelliklerinin Tayini. TSE EN ISO 5530-2, Ankara.

TSE (2016). Buğday ve Buğday Unu - Gluten İçeriği - Bölüm 2: Mekanik Yöntemle Yaş Gluten ve Gluten İndeksi Tayini. TS EN ISO 21415-2, Ankara.

TSE (2018). Buğday, TS 2974, Ankara.

Wang, K., Dupuis, B. \& Fu, B.X. (2017). Gluten aggregation behavior in high-shear-based glutopeak test: impact of flour water absorption and strength. Cereal Chemistry, 94(5), 909-915.

Wang, J., Hou, G.G., Liu, T., Wang, N. \& Bock, J. (2018). GlutoPeak method improvement for gluten aggregation measurement of whole wheat flour. LWT-Food Science and Technology, 90, 8-14.

Zawieja, B., Makowska, A. \& Gutsche, M. (2020). Prediction of selected rheological characteristics of wheat based on glutopeak test parameters. Journal of Cereal Science, 91, 102898. 